\title{
Locating Inca Terraces at Saqsaywaman to Restore the Original Drainage System and Protect the Great Walls
}

\author{
A Thesis \\ Presented to \\ the faculty of the School of Engineering and Applied Science \\ University of Virginia
}

In partial fulfillment of the requirements for the Degree

Master of Science

by

Gina Lisette O'Neil

May

2016 


\section{APPROVAL SHEET}

The thesis

is submitted in partial fulfillment of the requirements

for the degree of

Master of Science

Gina O’Neil

AUTHOR

The thesis has been read and approved by the examining committee:

Richard W. Miksad

\begin{tabular}{c}
\hline Advisor \\
Jonathan L. Goodall \\
\hline
\end{tabular}

Sean M. Ferguson

Accepted for the School of Engineering and Applied Science:

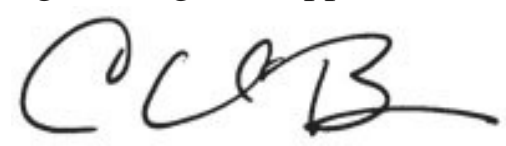

Craig H. Benson, Dean, School of Engineering and Applied Science May 


\section{ACKNOWLEDGEMENTS}

Thank you to all members of 2014 \& 2015 Research Teams

Richard W. Miksad, University of Virginia

Kenneth S. Lohr, Civil Engineering Graduate, University of Virginia

Teresa Jarriel, Civil Engineering Graduate student, University of Virginia

Edward Tiernen, Civil Engineering Undergraduate student, University of Virginia

Olivia Daniszewski, Civil Engineering Graduate, University of Virginia

Carmen Ortiz, Civil Engineering Graduate, Universidad Nacional de Ingeniería

Álvaro Javier, Civil Engineering Graduate, Universidad Nacional de Ingeniería

Jorge Soto, Civil Engineering Graduate, Universidad Nacional de Ingeniería

Frank Rojas, Civil Engineering Graduate, Universidad Ricardo Palma

Jose Galindo De La Cruz, Civil Engineering Graduate, Universidad Ricardo Palma

Kelley Frank, Civil Engineer, Kimley-Horn and Associates, Inc.

Zachary McColgan, Civil Engineering Graduate, University of Virginia

John Gathright, Data Engineer, Medical Division Network LLC.

Aaron Banasiewicz, General Science Undergraduate student, Fordham University

Jack Roswell, Undeclared Undergraduate student, Brown University

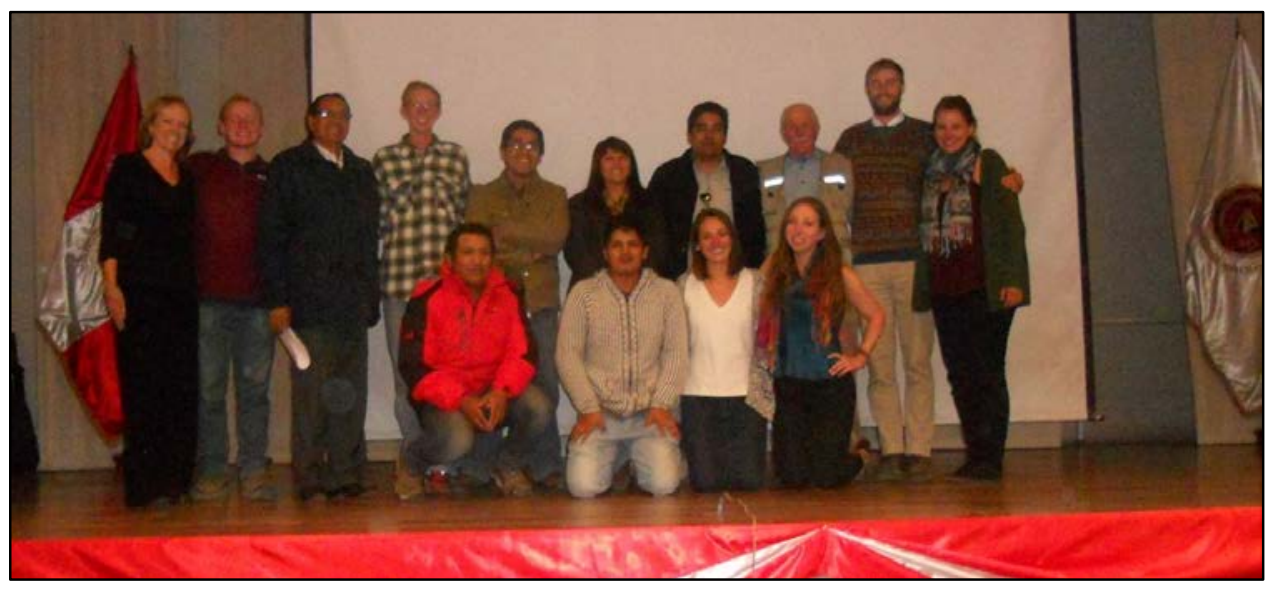


A special thanks to supervisors and contributors without whom this work would not have been possible.

Kenneth Wright, Project Sponsor, Wright Water Engineering

Dr. Ing. Jorge E. Alva Hurtado, Rector, Universidad Nacional de Ingeniería

Dr. Ing. Leonardo Alcayhuaman, Vice Rector Academico, Universidad Ricardo Palma

Alexei Vranich, UCLA Cotsen Institute of Archeology

Sr. Fermin Diaz Angulo, Project Sponsor, Office of Arq. Roberto Zegarra Alfaro, Gobierno Regional Cusco

Dr. Arminda Gibaja Oviedo, Chief Archaeologist, the National Institute of Culture at Cuzco

Lic. Mario Fernando Caller Salas, Project Coordinator, Oficina Central de Cultura UNI, Lima - Peru,

Ing. Jose Antonio Reynoso Palma, Parque de Saqsaywaman

Ing. Edith Quirquihuaña Zavala, Parque de Saqsaywaman

A very special thanks to Professor Richard Miksad, my advisor and mentor in conducting this research. He has been an invaluable resource of knowledge and enthusiasm throughout the course of this work. 


\section{ABSTRACT}

Saqsaywaman is a UNESCO World Heritage Site in Cusco, Peru constructed by the Inca in the $15^{\text {th }}$ century. It is recognized today as a remarkable Inca engineering feat, with its most impressive features being the three Great Walls that surround it. After withstanding centuries of abuse, the structural integrity of the walls has been compromised and they are beginning to collapse.

A three dimensional topographic model of Saqsaywaman revealed uncontrolled stormwater runoff to be the underlying threat to the Great Walls, resulting from the deterioration of the original Inca terracing system. Studies suggest the optimal method of protecting Saqsaywaman from further damage is to restore the Inca terracing system to its original intent to manage runoff at the site. While terrace remains are prominent on the surface of the site, the existence of a holistic terracing system at Saqsaywaman could not be justified by this alone. Thus, it was necessary to collect subsurface evidence of an Inca terracing system in addition to visual, above grade, evidence. By precisely documenting visual evidence of terraces, as well as conducting non-invasive subsurface analyses, a proposed configuration of the original terracing system was created.

This terrace configuration provides a plausible recreation of the original design of Saqsaywaman supported by engineering analysis. It serves as a foundation for future studies to protect Saqsaywaman by maintaining the historical integrity at the site. 


\section{TABLE OF CONTENTS}

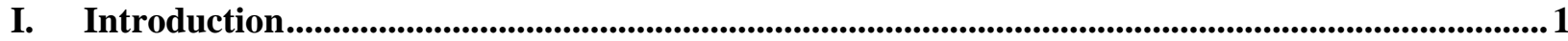

A. The Inca site of Saqsaywaman............................................................................................................. 1

B. Construction and Destruction of Saqsaywaman ................................................................................. 2

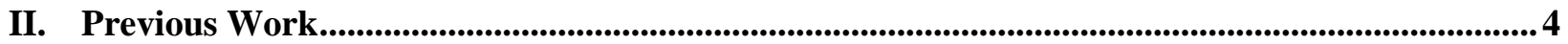

A. Indications of Failure................................................................................................................... 4

B. Assessing the Topography to Understand the Problem.................................................................5

III. Objective: Recreating a Hydrologically Sophisticated Terrace System ......................................8

IV. Specifications of an Inca Terracing System..............................................................................8

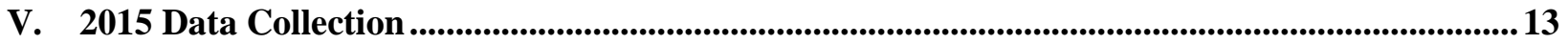

A. Total Station Data Collection ............................................................................................................... 15

B. Ground Penetrating Radar Data Collection....................................................................................... 18

C. Seismic Refraction Data Collection ......................................................................................................... 20

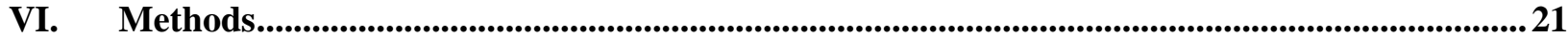

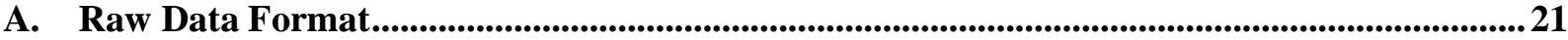

B. Adding Data to an ArcGIS Map ................................................................................................... 23

C. Task 1: Documenting 2015 Subsurface Data Collection ................................................................. 25

D. Task 2: Plotting significant points .......................................................................................................... 27

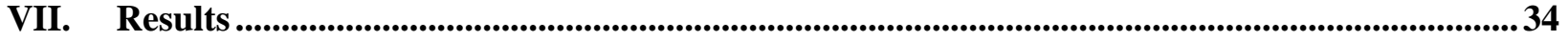

A. Interpreting 2015 Data to Locate Inca Terraces.............................................................................. 34

B. The Role of a Cohesive Terrace System in Managing Runoff at Saqsaywaman....................... 36

VIII. Conclusions ........................................................................................................................................... 37

IX. Recommendations ............................................................................................................................ 38

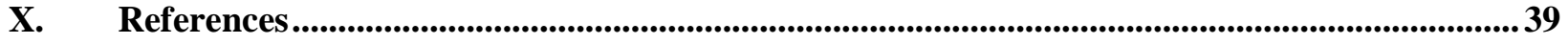

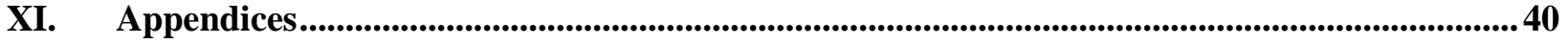

A. Saqsaywaman Geophysical Report ..................................................................................................40

B. Supplementary Subsurface Data Documentation .............................................................................. 48

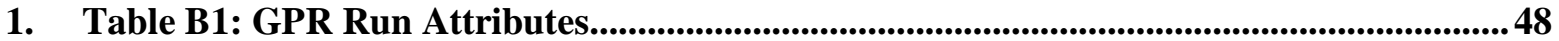

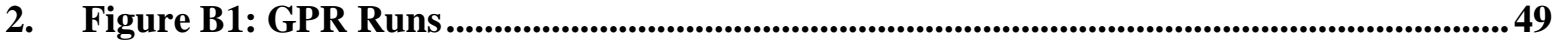

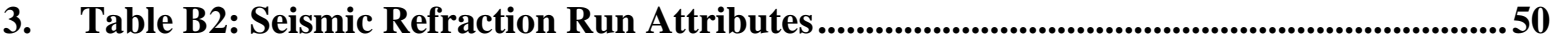

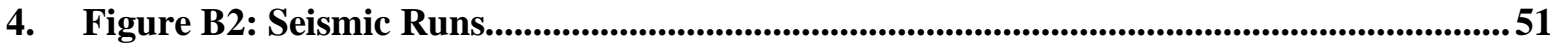




\section{List of Figures}

Figure 1: Location of Saqsaywaman relative to Cusco, Peru ................................................................ 1

Figure 2: The Great Walls of Saqsaywaman with labels for reference [12] ............................................ 2

Figure 3: Stones of the Great Walls of Saqsaywaman [1] ................................................................ 3

Figure 4: Cementitious clay ground cover (left) and location relative to rest of site (right) [11]................ 4

Figure 5: Collapsed section of $3^{\text {rd }}$ Wall due to increased runoff [12] ........................................................ 5

Figure 6: Screenshot of completed AutoCAD Topographic Model ...................................................... 6

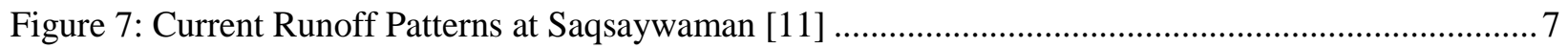

Figure 8: Map of Saqsaywaman as proposed by Gasparini and Margolies [6]......................................... 9

Figure 9: Runoff patterns at Saqsaywaman with terracing as proposed by Gasparini and Margolies [11] .. 9

Figure 10: Base channels used to direct runoff at Tipon [12] ............................................................ 10

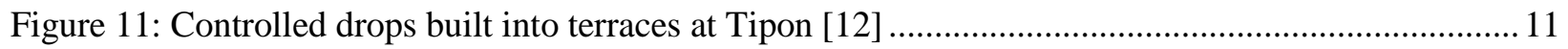

Figure 12: Hydraulic drop along stairs at Ollantaytambo [12] ............................................................ 12

Figure 13: Hydraulic drop along stairs at Suchana .............................................................................. 13

Figure 14: Locations of most frequently used benchmark points for 2015 Survey Data Collection.......... 16

Figure 15: Area of 2014 Survey Data Collection, shown on 3D Topographic Model of Saqsaywaman ... 17

Figure 16: Example of GPR return curve indicating a subsurface structure [13] .................................... 18

Figure 17: UVa and UNI engineers using the Quantum Imager to conduct GPR analyses at Saqsaywaman,

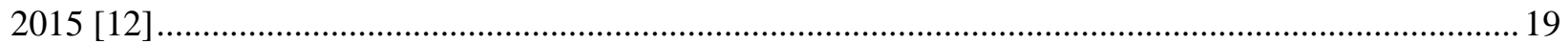

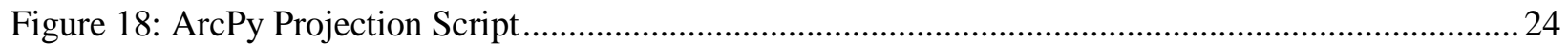

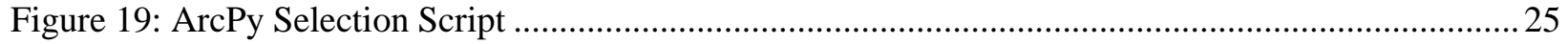

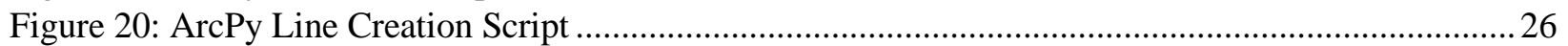

Figure 21: 2015 Subsurface Data Collection, documented with Quantum Imager GPR...........................27

Figure 22: Example of Structural Remains at Saqsaywaman [12] ......................................................... 28

Figure 23: Example of Terrace Remains at Saqsaywaman. Left shows a buried terrace, Right shows

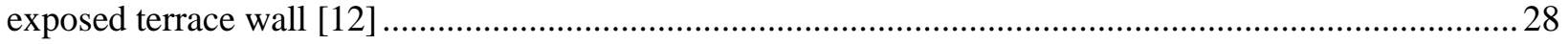

Figure 24: Existing Terraces on west side of Saqsaywaman [12] ..................................................... 29

Figure 25: Map of visual evidence of Inca Terraces, as documented by Total Station ............................. 30

Figure 26: Seismic Run labels corresponding to Table 5, yellow arrow indicates start of run, orange arrow indicates end of run. Provided by "Saqsaywaman Geophysical Report” ................................................. 31

Figure 27: All Collected Evidence of Inca Terrace Location .............................................................33

Figure 28: Inca Terrace Configuration based on 2015 Data Collection .................................................. 34

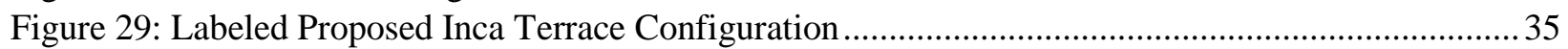

Figure 30: Flow patterns resulting from implementation of Inca Terrace Configuration........................... 37 


\section{List of Tables}

Table 1: Most frequently used benchmark points for 2015 Survey Data Collection ................................. 16

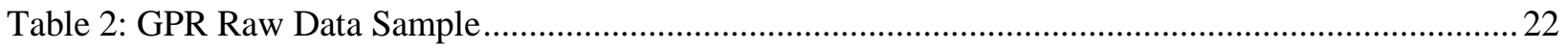

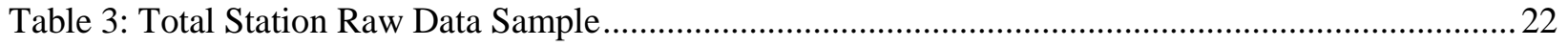

Table 4: Seismic Refraction Results, provided by “Saqsaywaman Geophysical Report”.......................... 32 


\section{INTRODUCTION}

\section{A. THE INCA SITE OF SAQSAYWAMAN}

Overlooking Cusco, Peru sits perhaps the most remarkable Inca engineering feat, Saqsaywaman (Figure 1). The most striking and impressive part of the complex are the three monolithic walls that delineate the north side of the site. Pictured in Figure 2, each of the three main walls is separated by approximately fifteen feet wide terraces running the full length of each wall. These walls are constructed of stones measuring over fifteen feet in height and weighing over 200 tons [5]. The precision and manpower necessary to construct the walls are testaments to the extent of power once held by the Inca Empire.

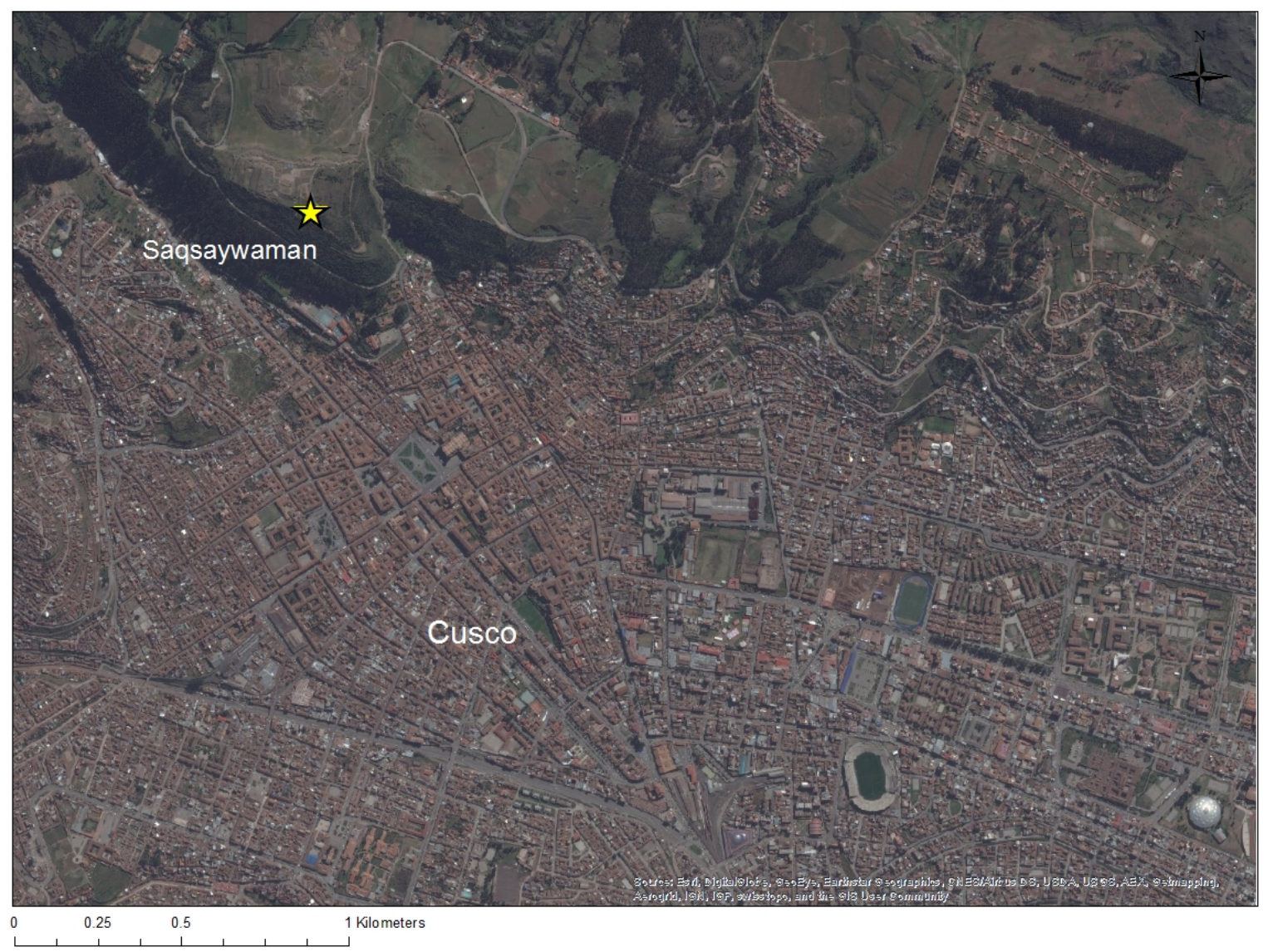

Figure 1: Location of Saqsaywaman relative to Cusco, Peru 


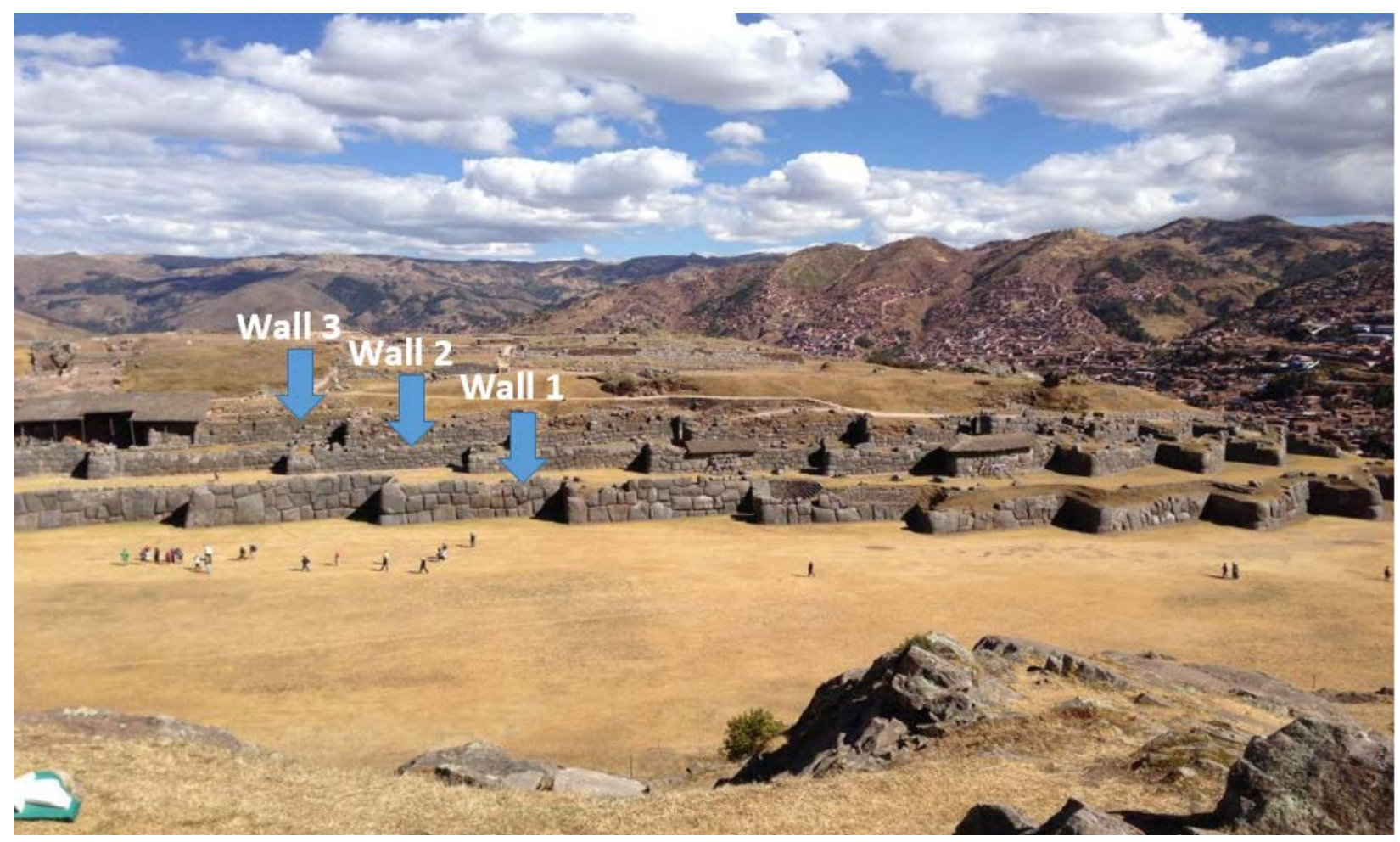

Figure 2: The Great Walls of Saqsaywaman with labels for reference [12]

\section{B. Construction and Destruction of SaQsaywaman}

Construction of Saqsaywaman began during the reign of the Inca Emperor and conqueror Pachacutec (1438-1472) and was continued by subsequent rulers until the arrival of Spanish conquistadors in 1532. Saqsaywaman is the largest monument constructed by the Inca, despite never being fully completed [8]. Many colonial Spanish accounts commonly referred to the site as The Fortress; however researchers now reject that Saqsaywaman served a sole military purpose. While the site features defensive structures, such as rampart-style walls, the abundance of high status stones and remnants of intricate architecture point to a more prestigious purpose. Thus, supposed defensive structures are proposed to have merely been barriers meant to prioritize the ceremonial use of plazas and to establish the accessibility to them for various classes of the population [10]. These massive stone structures display the engineering prowess of the Inca, who 
hand carved and fit each stone together without the use of mortar. Figure 3 illustrates the extraordinary size and fit of these stones.

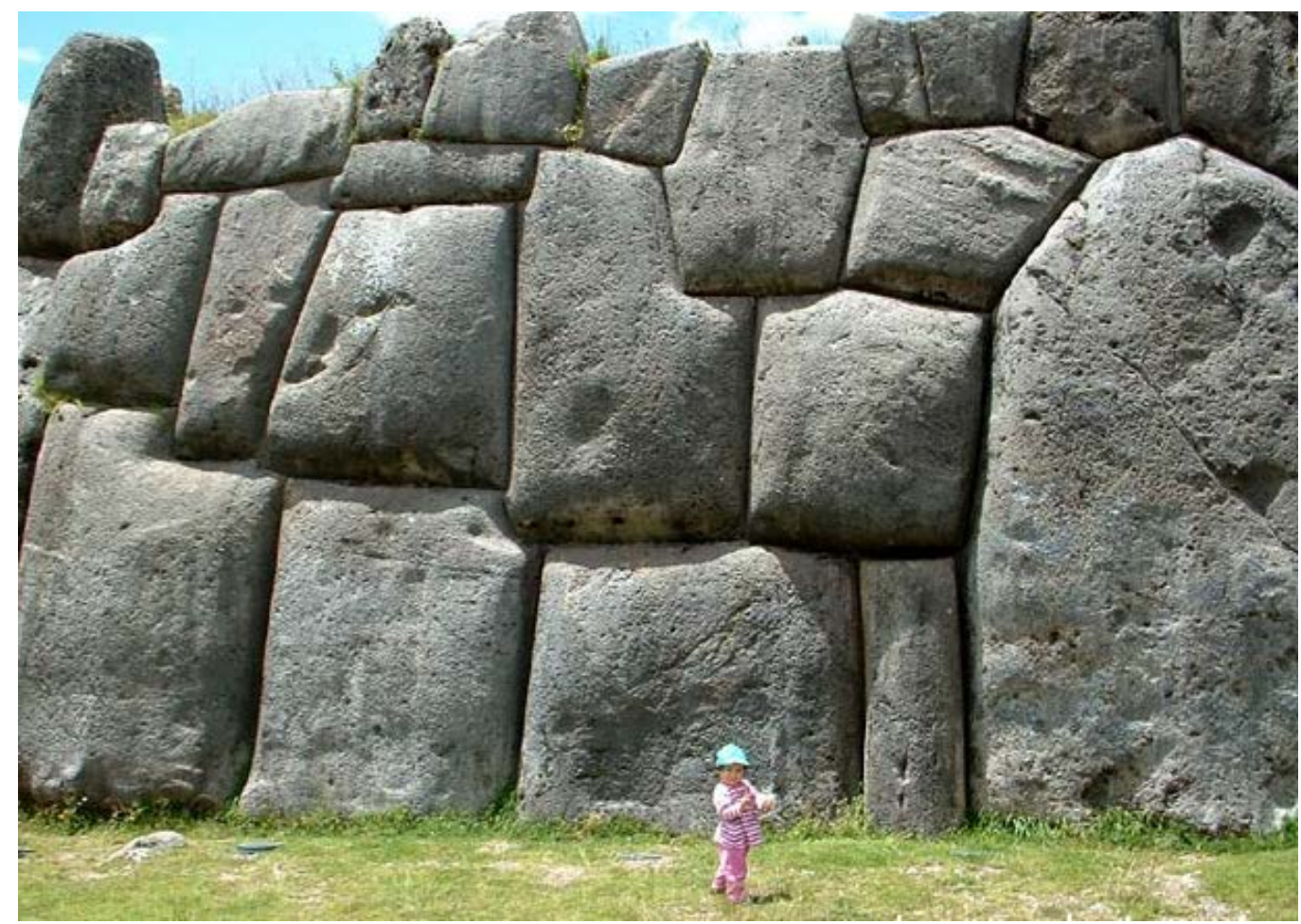

Figure 3: Stones of the Great Walls of Saqsaywaman [1]

The arrival of conquistadors in the $16^{\text {th }}$ century marked the beginning of abuse that Saqsaywaman would endure. Spaniards targeted the site and, within the first decades of the conquest, it was almost entirely destroyed. Conquistadors used the masonry of the site in building a Spanish Cusco, as affirmed by chronicler Garcilasco de la Vega. Even the aggression towards Saqsaywaman was a testament to its beauty, according to Garcilasco who suggested Saqsaywaman was more than a convenient source of cut stone to the Spaniards, it was a target of envy. Nonetheless, as a Spanish colonial city was erected, Saqsaywaman was reduced to ruins. However, the immense stones that the monolithic walls were made of were too difficult to dismantle, leaving the Great Walls as sole survivors of the violence [5]. Despite the efforts of the Institute of National Culture of Peru (INC) 
to protect and maintain the site today, detrimental changes to Saqsaywaman continue to put the walls in danger.

\section{PREVIOUS WORK}

\section{A. INDICATIONS OF FAILURE}

Previous studies have concluded that the years of maltreatment at the site have resulted in the destruction of utilitarian Inca structures. The effect of these losses is best summarized as the disruption of the original Inca drainage system. Without an effective method of diverting storm water away from remaining structures, they face an imminent threat of failure. The first realization of this threat came in 2009, after the addition of an impervious clay ground cover meant to preserve excavated ruins above the third wall (Figure 4).
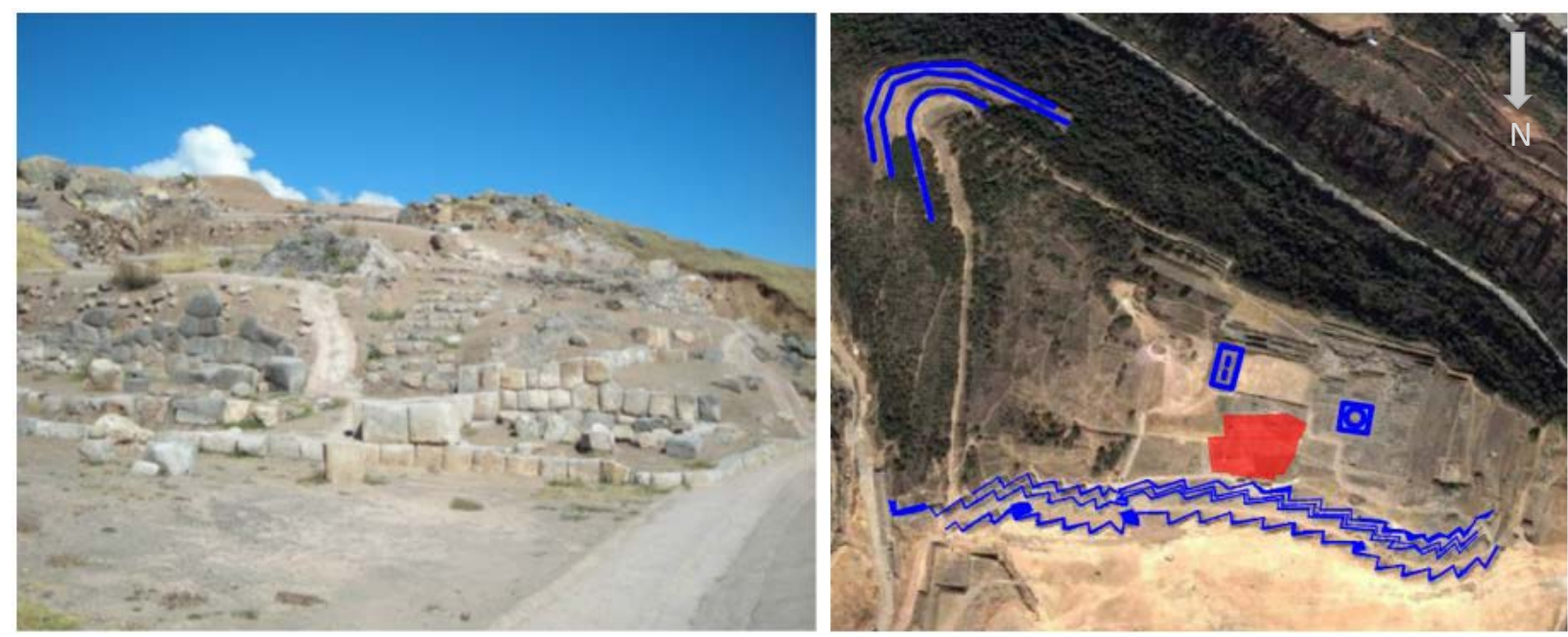

Figure 4: Cementitious clay ground cover (left) and location relative to rest of site (right) [11]

The addition of impervious ground cover increased runoff towards the third wall, leading to a major collapse along the wall (Figure 5). A hydrologic analysis of the site performed by Wildfire et al. determined the cause of the collapse to be a large buildup of hydrostatic pressure behind the stones of the walls, pushing them outward. It was concluded that the hydrostatic pressure buildup 
was caused by a 70\% increase in runoff resulting from of the addition of the cementitious clay [17]. The INC has attempted to abate excess runoff in this section, and additional locations around the site, with the implementation of ad hoc drainage channels. However, these unsophisticated hydrologic systems were unable to properly control runoff [11]. The realization that uncontrolled runoff continued to pose a threat to the site motivated a complete evaluation of the runoff at Saqsaywaman.

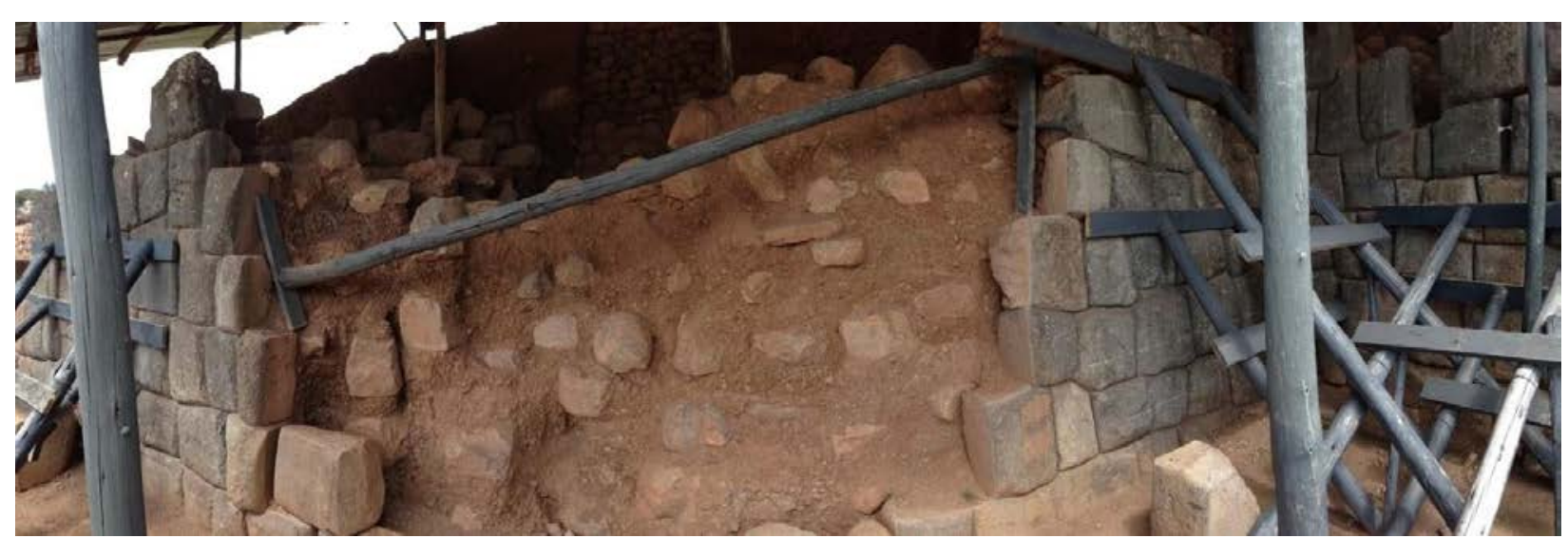

Figure 5: Collapsed section of $3^{\text {rd }}$ Wall due to increased runoff [12]

\section{B. Assessing the Topography to Understand the Problem}

In 2014, I was a part of a University of Virginia team conducting field studies to evaluate the runoff at Saqsaywaman. These studies were a continuation of similar field research that took place in the summers of 2012 and 2013, also by University of Virginia teams. Understanding the extent of the problem at the site was a crucial prerequisite to determine how best to preserve the structural integrity of the three megalithic walls. All field research focused on collecting survey data to create an accurate three-dimensional topographic model of Saqsaywaman with AutoCAD. The topographic data, collected with a TopCon GTS-230W series, had amounted to over 5,000 points in 2014. The model (Figure 6) was completed and shared with the National Institute of Culture of Cusco in 2015. 


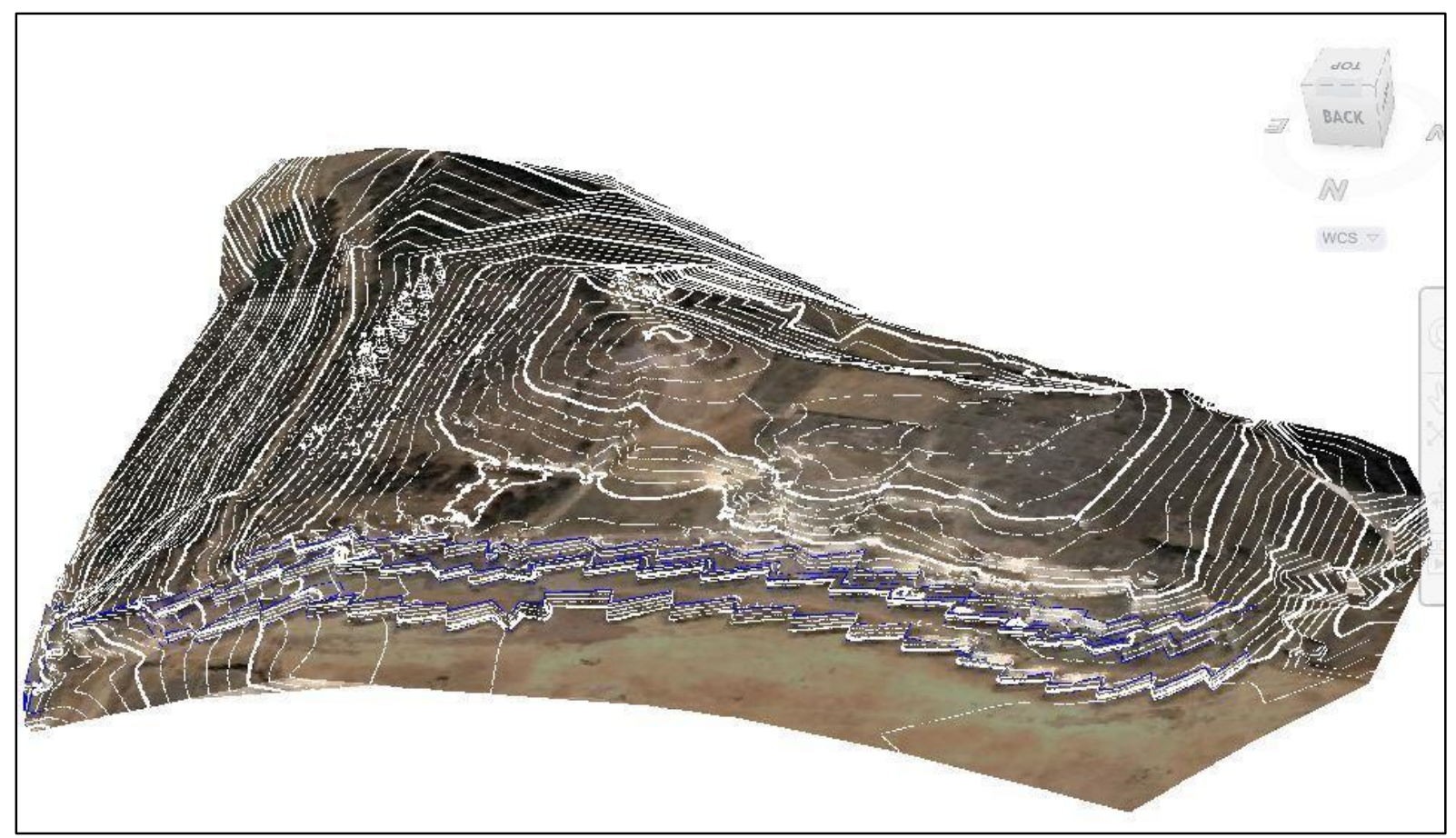

Figure 6: Screenshot of completed AutoCAD Topographic Model

The three dimensional model of Saqsaywaman was used to generate flow patterns due to topography at the site. Figure 7 shows present-day runoff patterns with arrows that indicate both direction and quantity of runoff. The patterns show that most of the water beginning at the northern portion of the site is channeled directly towards the walls. Having no method to divert runoff along any of the terraces, water can continue to flow over the Great Walls to lower terraces. It is not consistent with Inca design to allow water to cross terraces freely, as is shown in this simulation. Instead, it would be expected that Inca engineers would have implemented a hydrologically 
sophisticated terracing system to divert runoff away from the most impressive structures of their site [11].

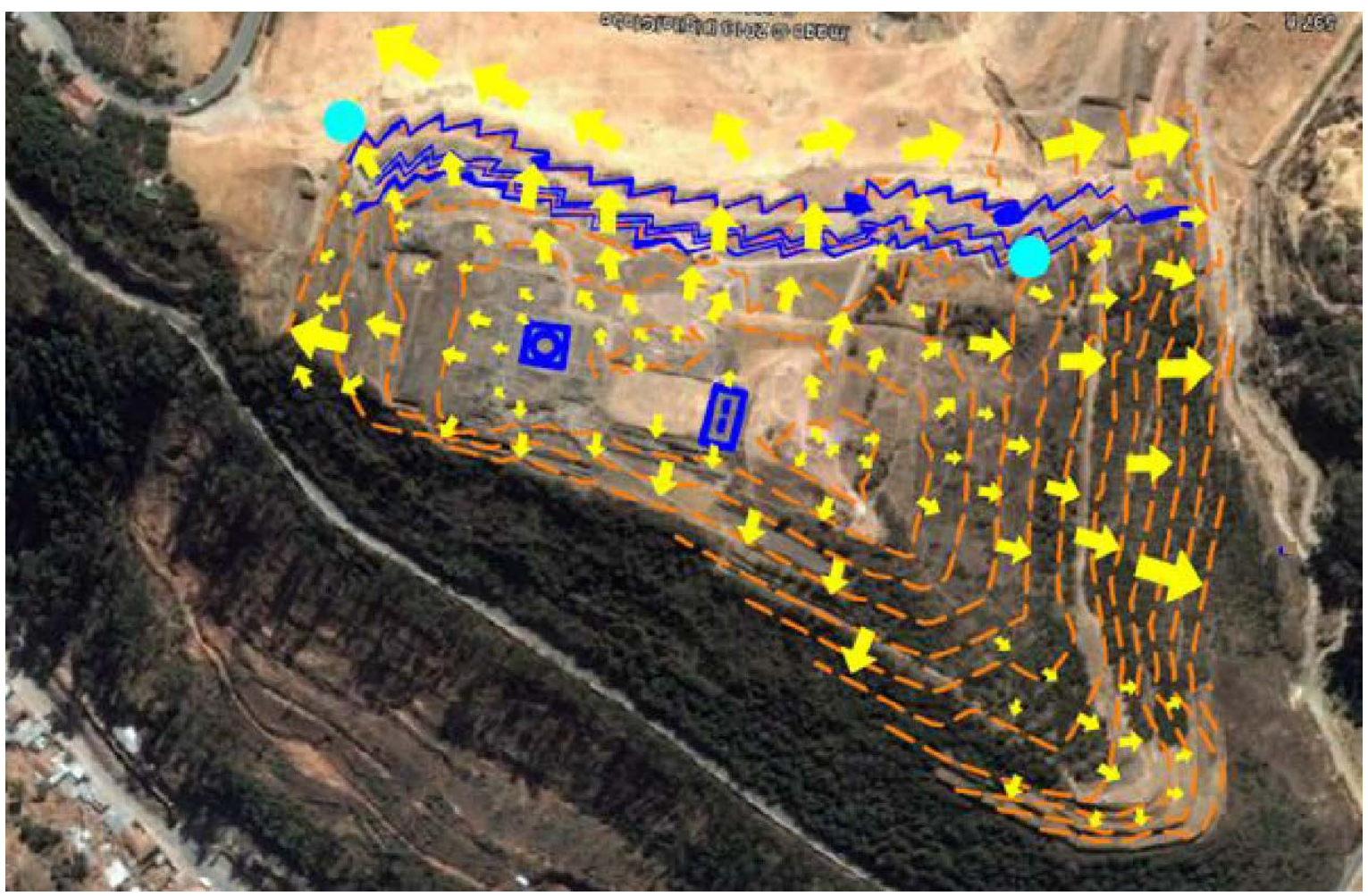

Figure 7: Current Runoff Patterns at Saqsaywaman [11]

Analyses performed with the three dimensional model have made it clear that excess and uncontrolled runoff is a persisting and grave threat to the site. Additionally, more critical areas along the third wall have been reported since August of 2014. Unless this problem is remedied, further structural degradation is likely [14]. With this motivation, a critical question arises: How can runoff be managed in a way that protects the Great Walls of Saqsaywaman and maintains the historical integrity of the site? 


\section{ObJeCtive: ReCREATING a HydROLOGICALly SOPHISTICATED TERRACE SYSTEM}

Our studies demonstrate that the optimal solution to this question is to implement a hydrologically sophisticated terrace system that would prevent further damage to the Great Walls caused by stormwater runoff. To validate this hypothesis, I organized and took part in field research conducted in order to collect evidence of Inca Terraces at Saqsaywaman. Members of this 2015 research team included engineers from the University of Virginia (UVa), Universidad Nacional de Ingeniería (UNI), and Universidad de Ricardo Palma (RP). I used the resulting data to establish the configuration of a hydrologically sophisticated Inca terracing system, which demonstrates the ability to divert stormwater runoff away from the Great Walls.

\section{SPECIFICATIONS OF AN INCA TERRACING SYSTEM}

In order for a hydrologic terracing system to function at an Inca-level of sophistication, it would have to exhibit three key attributes. First, (i) terrace grades would direct runoff laterally away from the Great Walls and then along terrace paths. This conclusion is drawn from the studies of Gasparini and Margolies, who proposed that the site originally had terraces running concentrically around the hill and steadily rising in elevation (Figure 8), a feature characteristic of other Inca sites [11]. Taking into account contours proposed by Gasparini and Margolies, flow directions were modeled (Figure 9). This model leads to important conclusions about the intended drainage plans following completion; runoff is directed laterally to the east and west and then south along terraced paths [11]. 


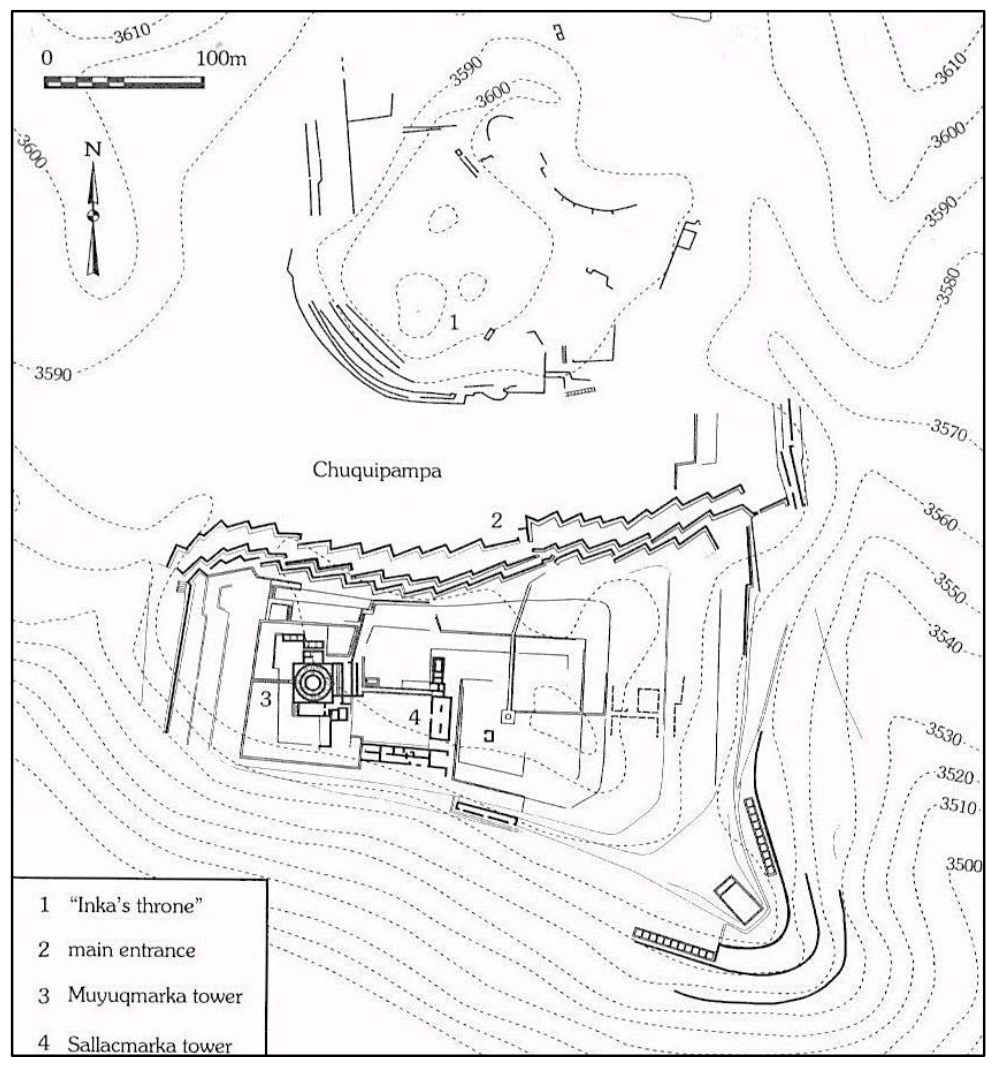

Figure 8: Map of Saqsaywaman as proposed by Gasparini and Margolies [6]

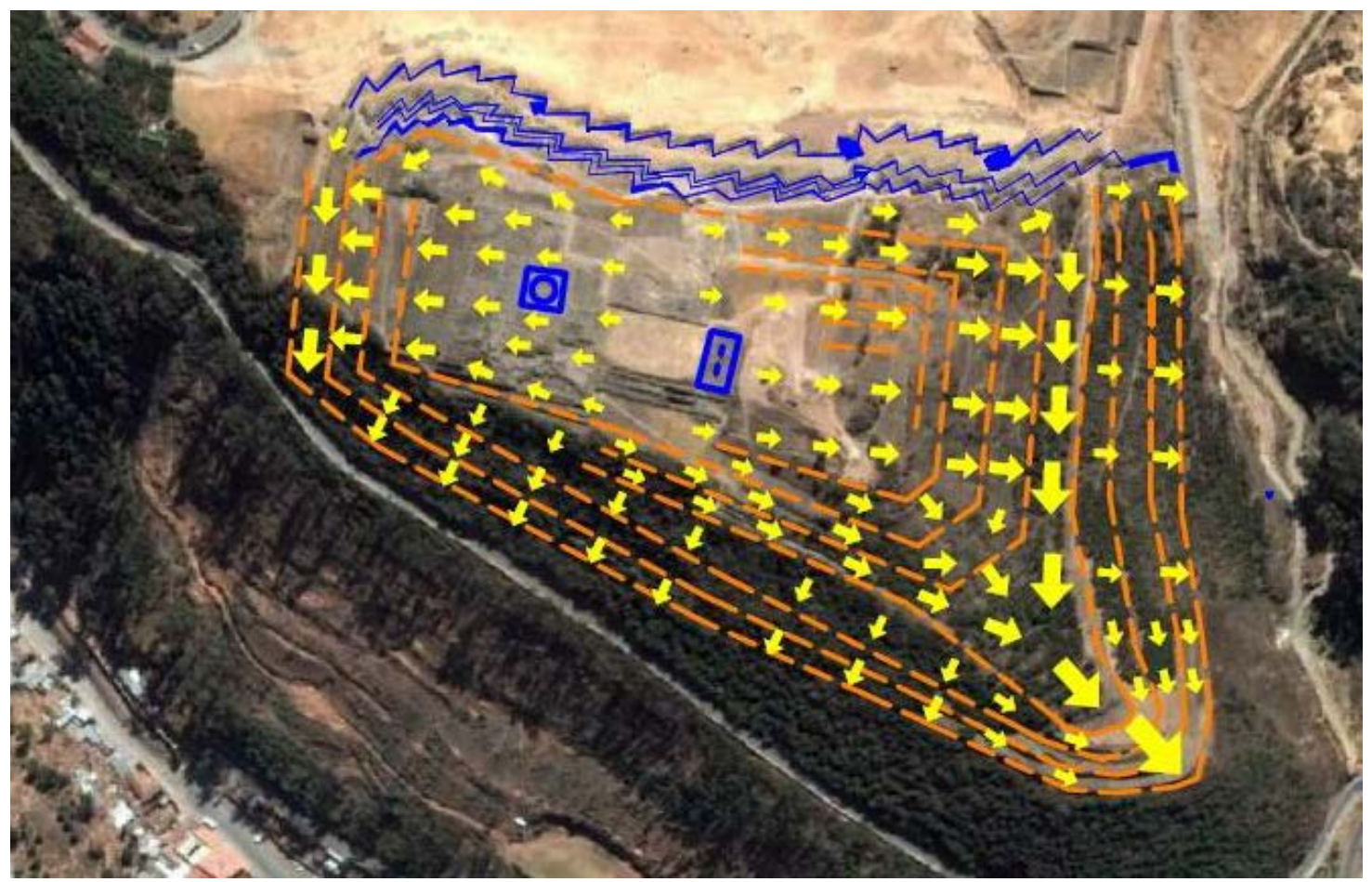

Figure 9: Runoff patterns at Saqsaywaman with terracing as proposed by Gasparini and Margolies [11] 
Assuming consistency among Inca architectural techniques, two additional conditions would be met by an Inca terracing system: (ii) runoff would be transported via base channels along terraces and (iii) runoff would only move from terrace to terrace through controlled drops. Tipon is an Inca site where there still exists a well-defined and functioning runoff management system that meets these conditions. This system consists of terraces with base channels, which serve the purpose of directing storm runoff (Figure 10).

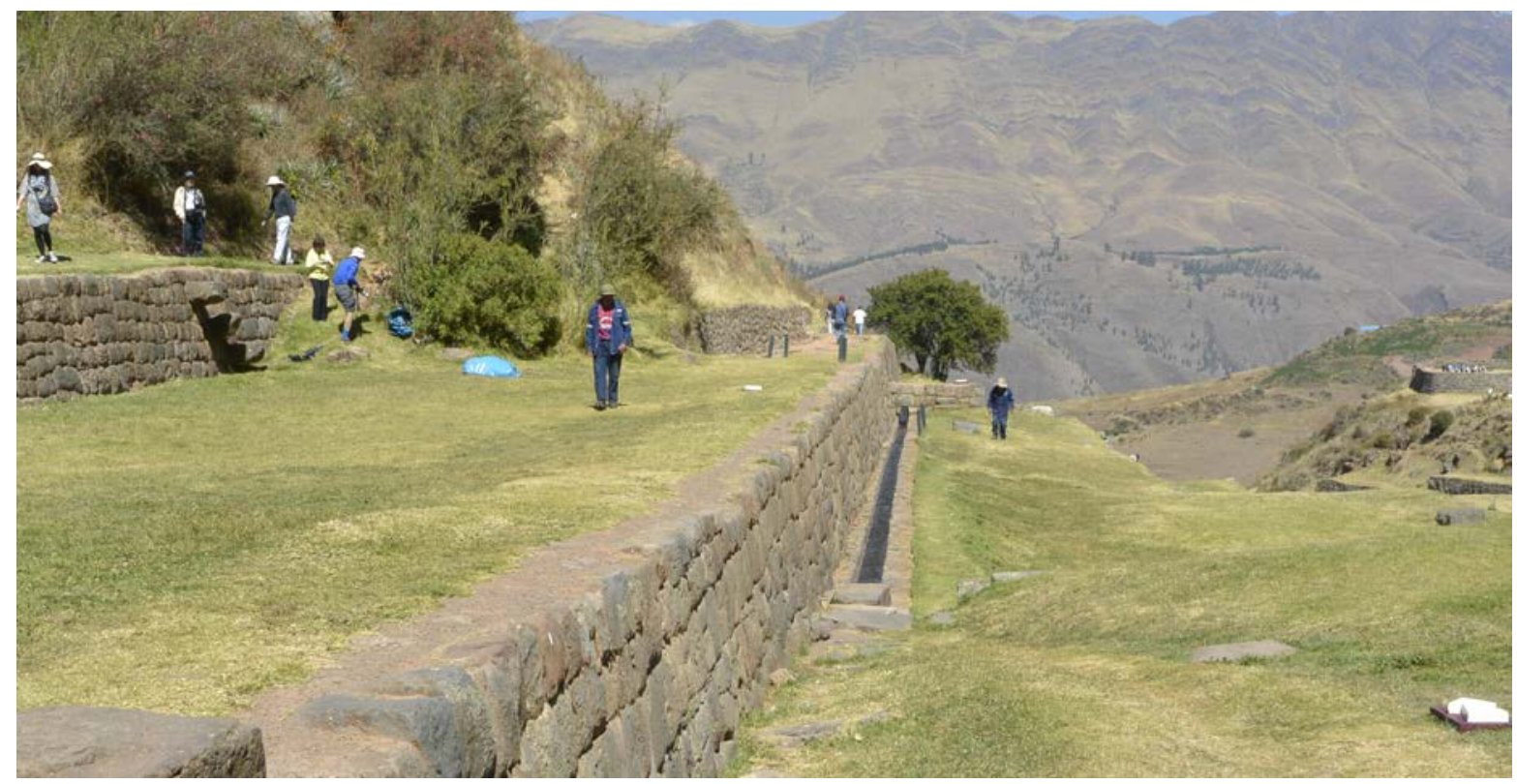

Figure 10: Base channels used to direct runoff at Tipon [12] 
As seen in Figure 11, Tipon terraces also feature controlled drops along which runoff is transferred from higher terraces to lower ones.

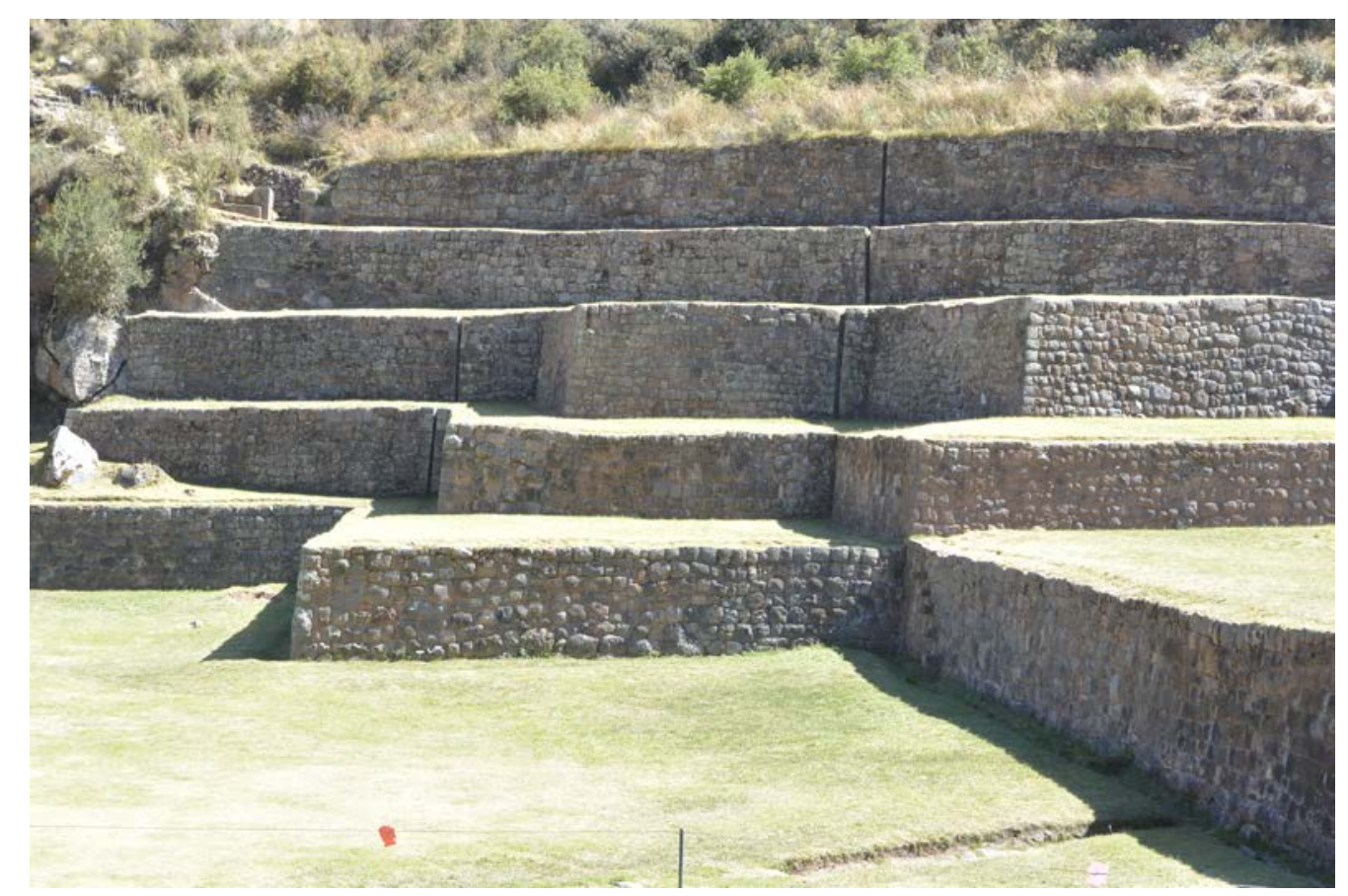

Figure 11: Controlled drops built into terraces at Tipon [12]

Ollantaytambo, a Sun Temple built by the Incas, has a different method of transporting water from terrace to terrace. At this site, stairways are constructed with base channels and act as the 
mechanism to transport water to lower elevations (Figure 12). This alternate hydraulic drop is also seen at Suchana, a small Inca structure located directly across from Saqsaywaman (Figure 13).

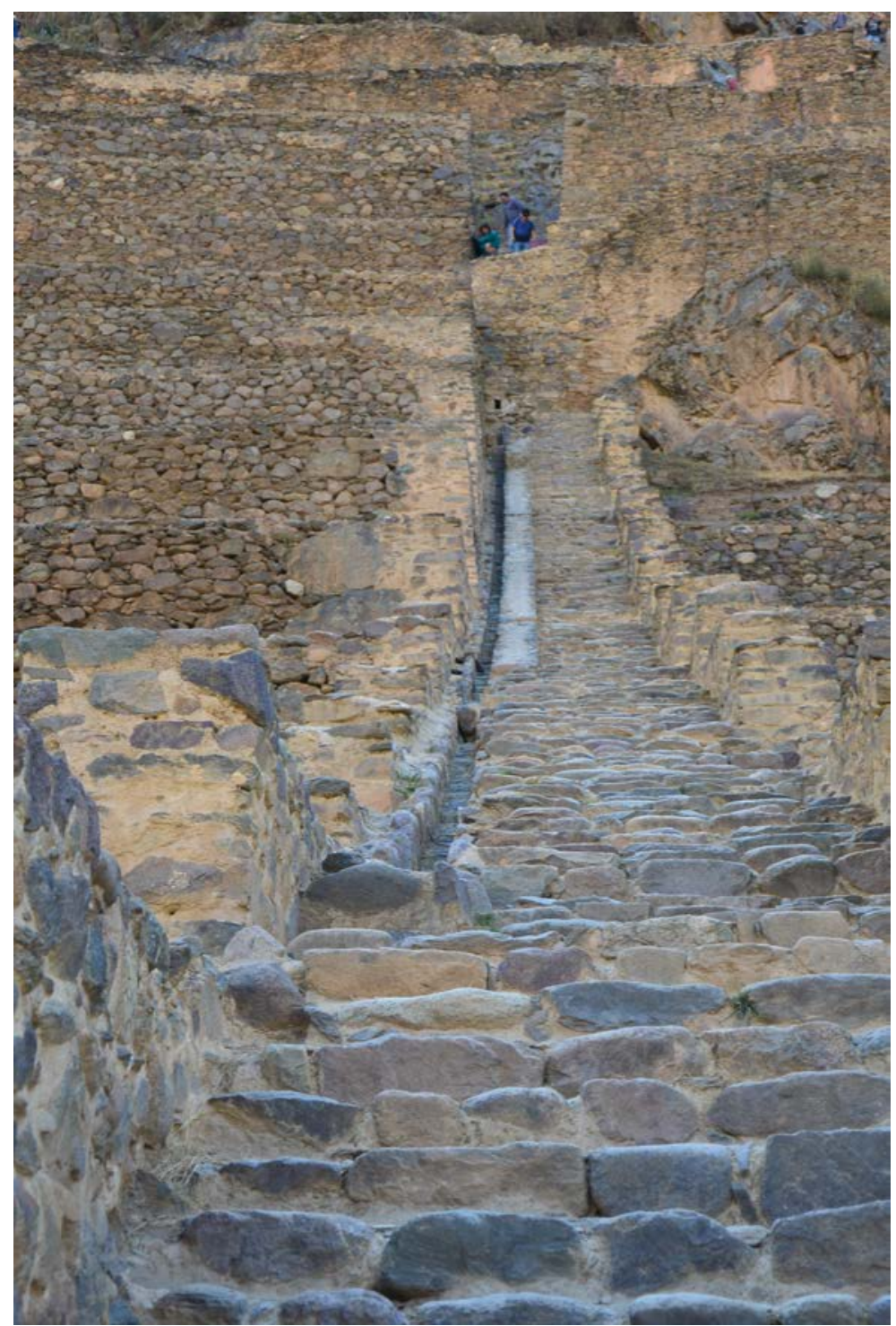

Figure 12: Hydraulic drop along stairs at Ollantaytambo [12] 


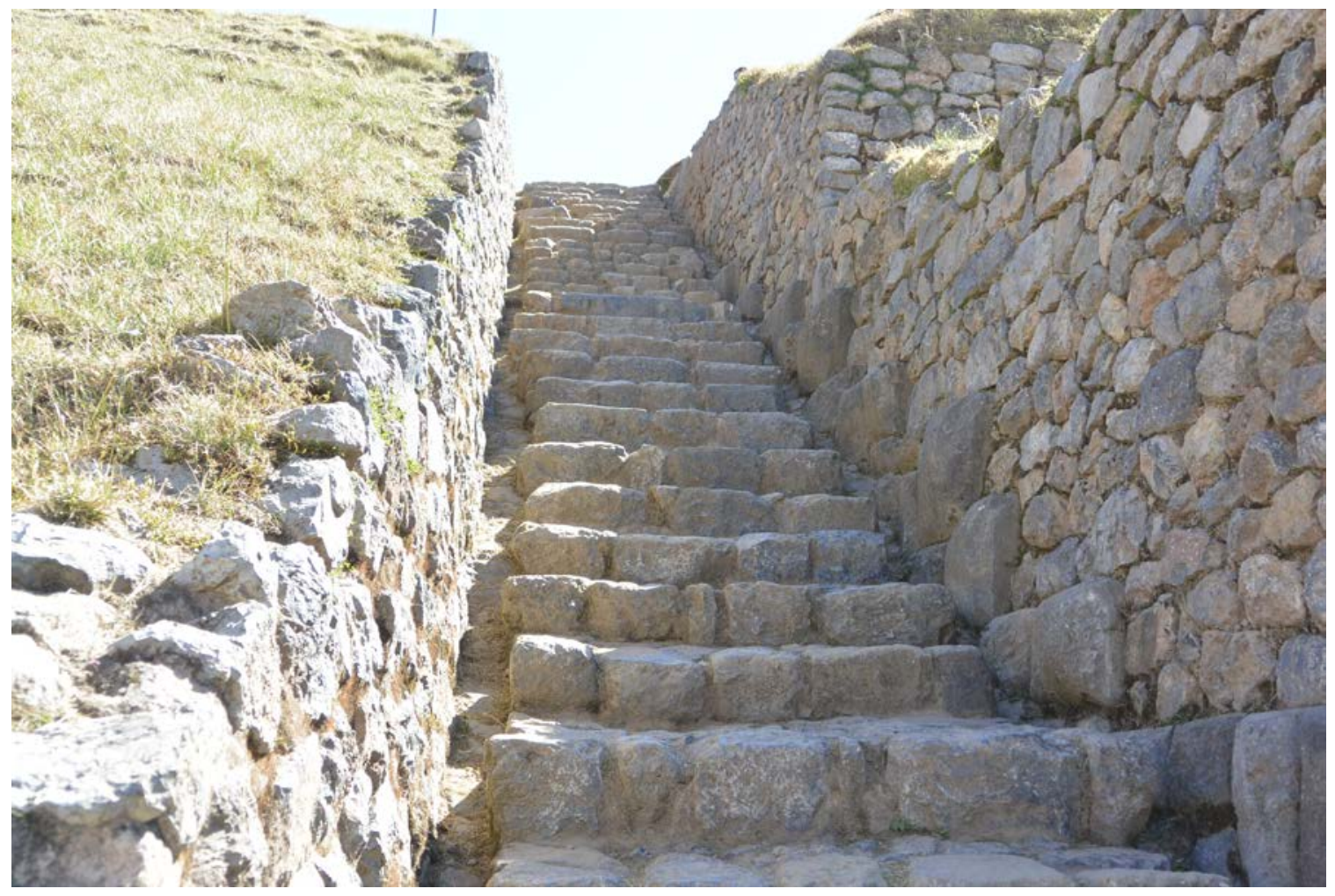

Figure 13: Hydraulic drop along stairs at Suchana

For these reasons, a hydrologically sophisticated terracing system designed by the Incas would feature three critical attributes: (i) Inca terraces would ultimately drain to southeast and southwest corners of the site, (ii) runoff would be transported via base channels along terraces, and (iii) runoff would be allowed to cross terraces through controlled drops.

\section{2015 DATA COLLECTION}

Although visual evidence of Inca terraces is prominent at Saqsaywaman, supplemental subsurface evidence was needed to determine their locations. Due to the cultural sensitivity of the site, it was imperative that only non-invasive subsurface analysis was conducted. For that reason, seismic refraction and GPR measurements were taken to corroborate the fact that there are buried obstructions indicating terraces. By using the points that trace each of these runs, the exact 
locations of these obstructions could be found, and a "path" of data points could be used to delineate the original Inca terraces.

Above grade evidence represents physical proof of dismantled structures, whereas subsurface data can only indicate a non-specific object in the ground. For this reason, the precise locations of visual evidence gathered by this team not only directed subsurface data collection, but also acted as a guide and intermediate benchmarks when subsequently analyzing subsurface data for patterns.

GPR analysis was an appropriate method for this application because it has wide acceptance in the archaeological community as a method that can quickly and accurately locate buried archeological features in the near-surface. As early as the 1970s, GPR was being used to image buried walls at Chaco Canyon, New Mexico. Later in the mid-1990s, GPR surveys were conducted in Japan to locate sixth-century houses and burial mounds. These studies were deemed accurate after excavations confirmed the results [9]. These successes were followed by numerous other Japanese GPR surveys, resulting in the recognition of GPR as a planning tool for selective excavation [4].

Seismic refraction was also chosen to collect subsurface data for its history as a tool for selective excavations. For instance, in Northern Greece, seismic refraction was used to detect monumental tombs. In this case, seismic refraction located buried tombs and allowed for selective excavation without harming the artifacts [15]. Additionally, seismic methods were used to reveal details at the archeological site of Los Millares in Almería, Spain. The application of this method provided information in a non-destructive manner that resulted in the determination of the calcaric surface upon which foundations were built [3]. 


\section{A. Total Station Data Collection}

To gather the necessary surface data, a Topcon GTS-240 NW Series electronic Total Station and accompanying prism were used (Figure 14). Data was recorded in the Universal Transverse Mercator (UTM) Coordinate system and each measured point had attributes of Northing, Easting, and Elevation. When properly operated, the Topcon GTS-240 NW has an accuracy of $\pm 2 \mathrm{~mm}$. [7].

The Total Station was operated by the Total Station team, consisting of myself and other UVa engineers. We sought to precisely document locations of visual evidence of terrace remains. To do so, points were taken along partially exposed structural and terrace remains and sudden changes in topography. When plotted on a map or imported into the AutoCAD model, these points would guide the extension of current terraces or creation of previously unrecognized Inca Terraces.

To begin surveying, the Total Station had to first be set up at a benchmark point of known location. Benchmark points used throughout this project began with two geodetic survey markers on the site and expanded to include UVa-created benchmark points. Once at a benchmark point, the Total Station had to be leveled and a backsight was taken at another known location. At this point, the Total Station would orient itself in space and desired points could be recorded. Points could be recorded from the same set up location until the prism, held over the desired point, was no longer in view of the Total Station. When desired points became out of range of sight of the Total Station, the set-up procedure would be repeated at a different benchmark point. Table 1 shows benchmark points used for the 2015 Survey Data Collection, and Figure 14 shows the corresponding locations. 
Table 1: Most frequently used benchmark points for 2015 Survey Data Collection

\begin{tabular}{|r|l|r|r|r|}
\hline \multicolumn{1}{|c|}{ Point ID } & \multicolumn{1}{|c|}{ Point Description } & Northing [m] & Easting [m] & Elevation [m] \\
\hline 1 & UVA-2013 & 8504811.3 & 177126.4 & 3602.6 \\
\hline 2 & Muyucmarca & 8504585.3 & 177057.1 & 3601.6 \\
\hline 3 & UVA-2015 & 8504609.5 & 177157.2 & 3597.3 \\
\hline 4 & TP1.15 & 8504570.2 & 177227.0 & 3598.7 \\
\hline 5 & TP2.15 & 8504601.9 & 177278.1 & 3586.2 \\
\hline 6 & TP8.15 & 8504650.8 & 177013.0 & 3591.7 \\
\hline 7 & Suchana & 8504851.1 & 177145.3 & 3606.6 \\
\hline
\end{tabular}

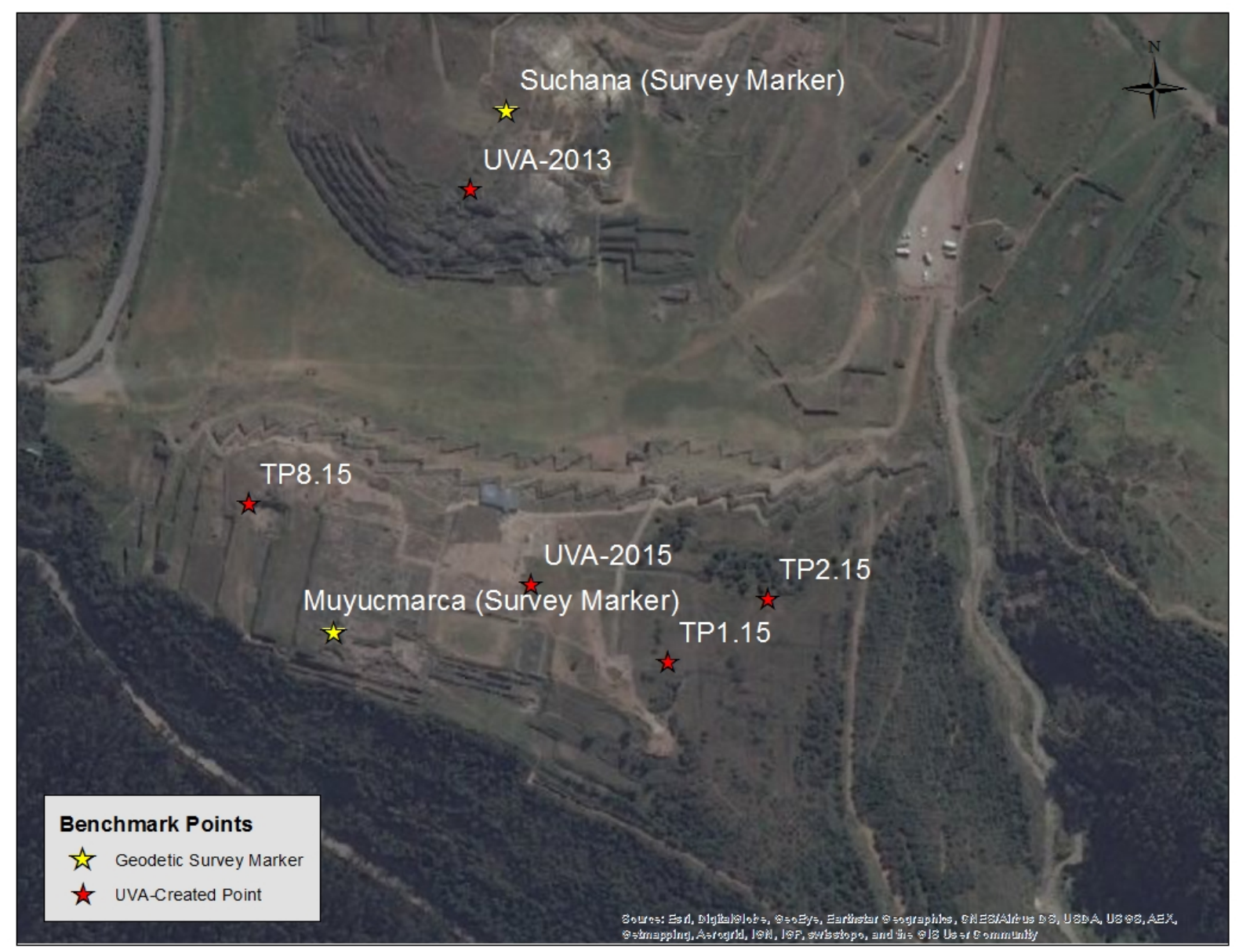

Figure 14: Locations of most frequently used benchmark points for 2015 Survey Data Collection

The majority of protruding walls, partially exposed stone, and sudden topographic changes occurred on the east side of Saqsaywaman. Even though the eastern portion of the site does not 
face the Great Walls, terracing along this sector is still crucial to the redirection of runoff. The objective of this research was to implement a holistic terrace system that not only diverts runoff away from the walls, but continues to channel it to a final drainage location. For this reason, most Total Station data collection occurred in the area indicated in Figure 15.

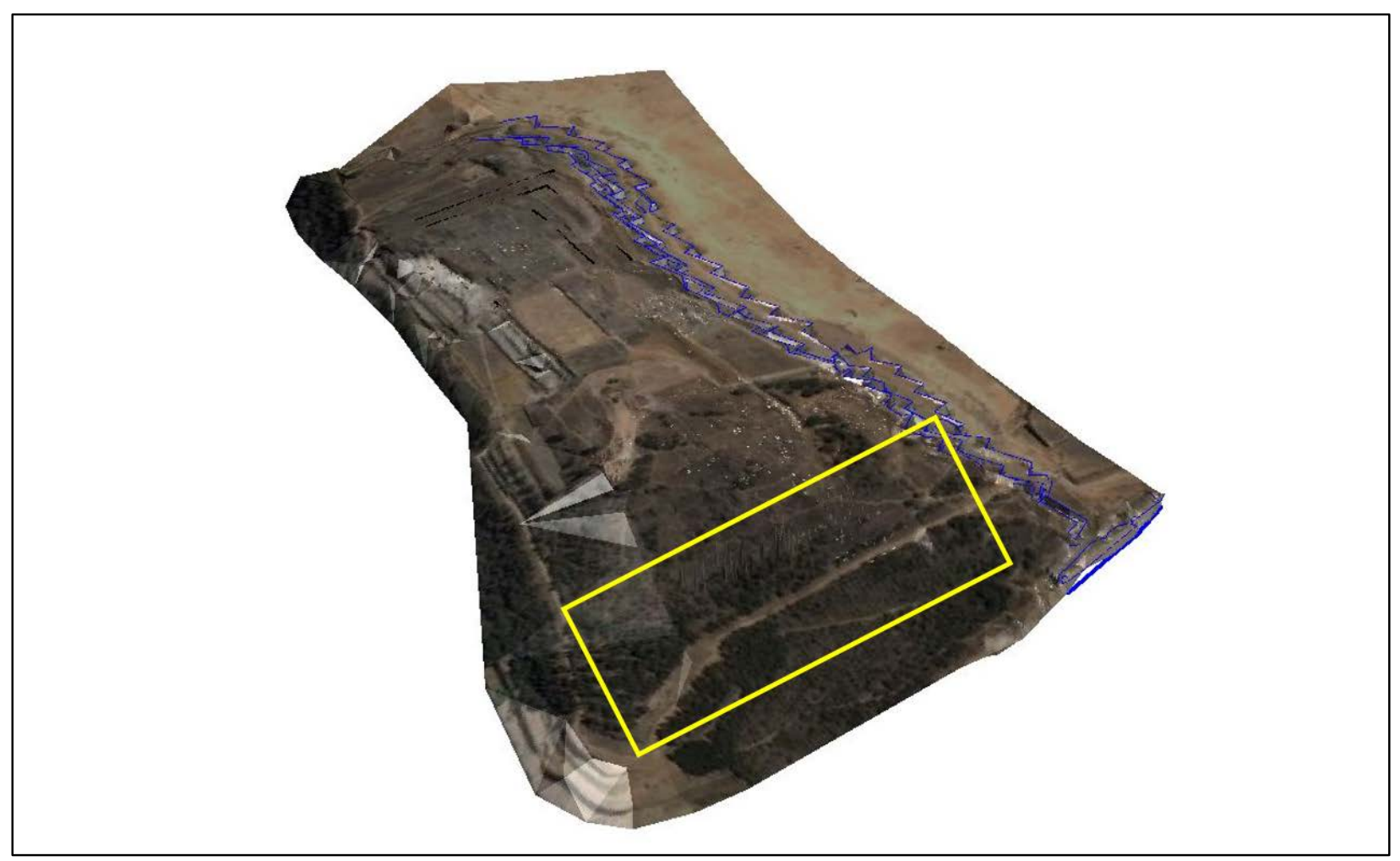

Figure 15: Area of 2014 Survey Data Collection, shown on 3D Topographic Model of Saqsaywaman

Some challenges and sources of error arose during the project due to poor maintenance in the area of data collection. This section has overgrown vegetation, which at times made it difficult to obtain a clear line of sight between the Total Station and prism. Also, because of careless excavations in this area, it was difficult at times to distinguish significant elevation jumps from mounds of debris. 


\section{B. Ground Penetrating Radar Data Collection}

The Ground Penetrating Radar (GPR) was operated by the GPR team, consisting of UVa and UNI engineers. The Quantum Imager Ground Penetrating Radar was used for 2015 data collection. Using the same principles by which sonar systems detect objects under water, GPR uses radio waves, at approximately $200 \mathrm{MHz}$, to detect objects in the soil medium. When radio waves impact a substance of a different density from the ambient soil, some of the energy of the wave is reflected back and the GPR determines how deep underground the obstruction is [13]. Figure 16 shows an example GPR return curves detecting obstructions, which look like dark hyperbolas on a yellow ambient background.

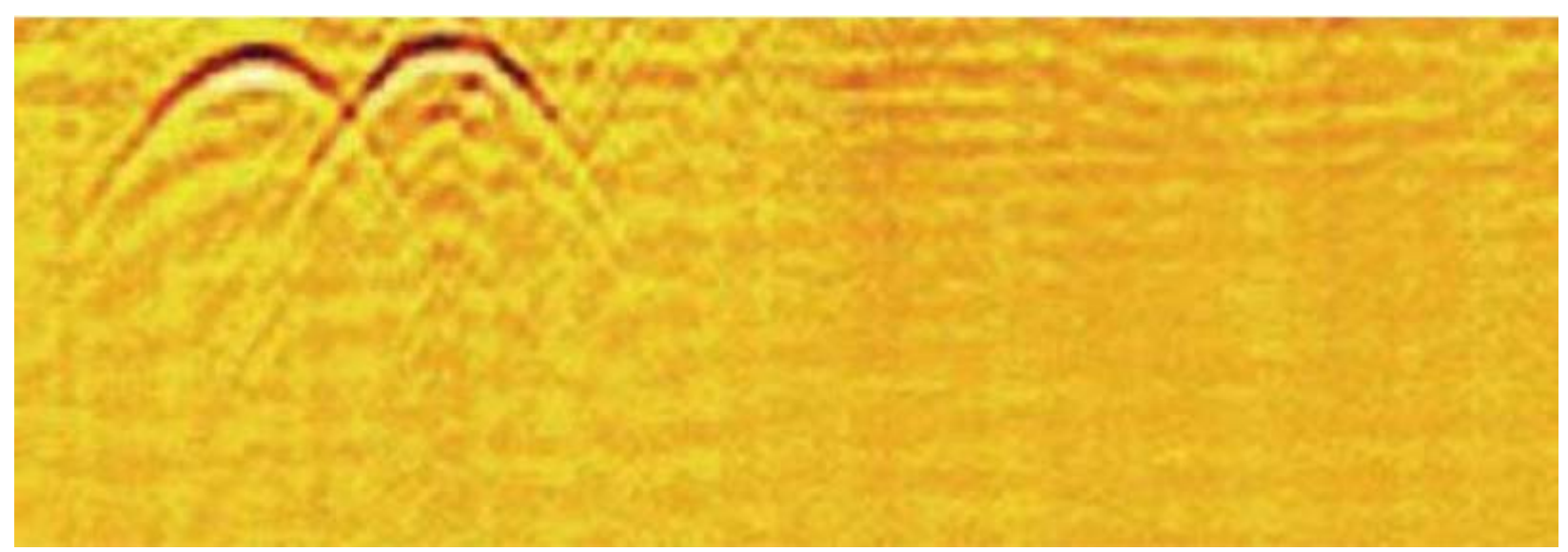

Figure 16: Example of GPR return curve indicating a subsurface structure [13]

The GPR team had two objectives. First was to collect subsurface data at inferred locations of Inca Terraces, and second to document locations and lengths of runs taken by GPR and Seismic Refraction. The Quantum Imager was well equipped to meet these tasks as it can detect disturbances at depths of up to 5 meters and has external GPS capabilities [13]. Once a run was conducted, points on the tablet screen could be chosen and marked with a survey point, and all survey points could then be exported as csv files. These points included subsurface anomalies, which satisfied data needed to meet the first objective, and start and end points of runs, to satisfy 
data needed to meet the second objective. The GPR team took most of its measurements in the same eastern portion of the site as the Total Station team. Additionally, GPR runs were taken anywhere that Seismic Refraction runs were taken, not only to document locations but also to be able to directly compare anomalies between both techniques. Figure 17 shows GPR data being collected at Saqsaywaman with the Quantum Imager.

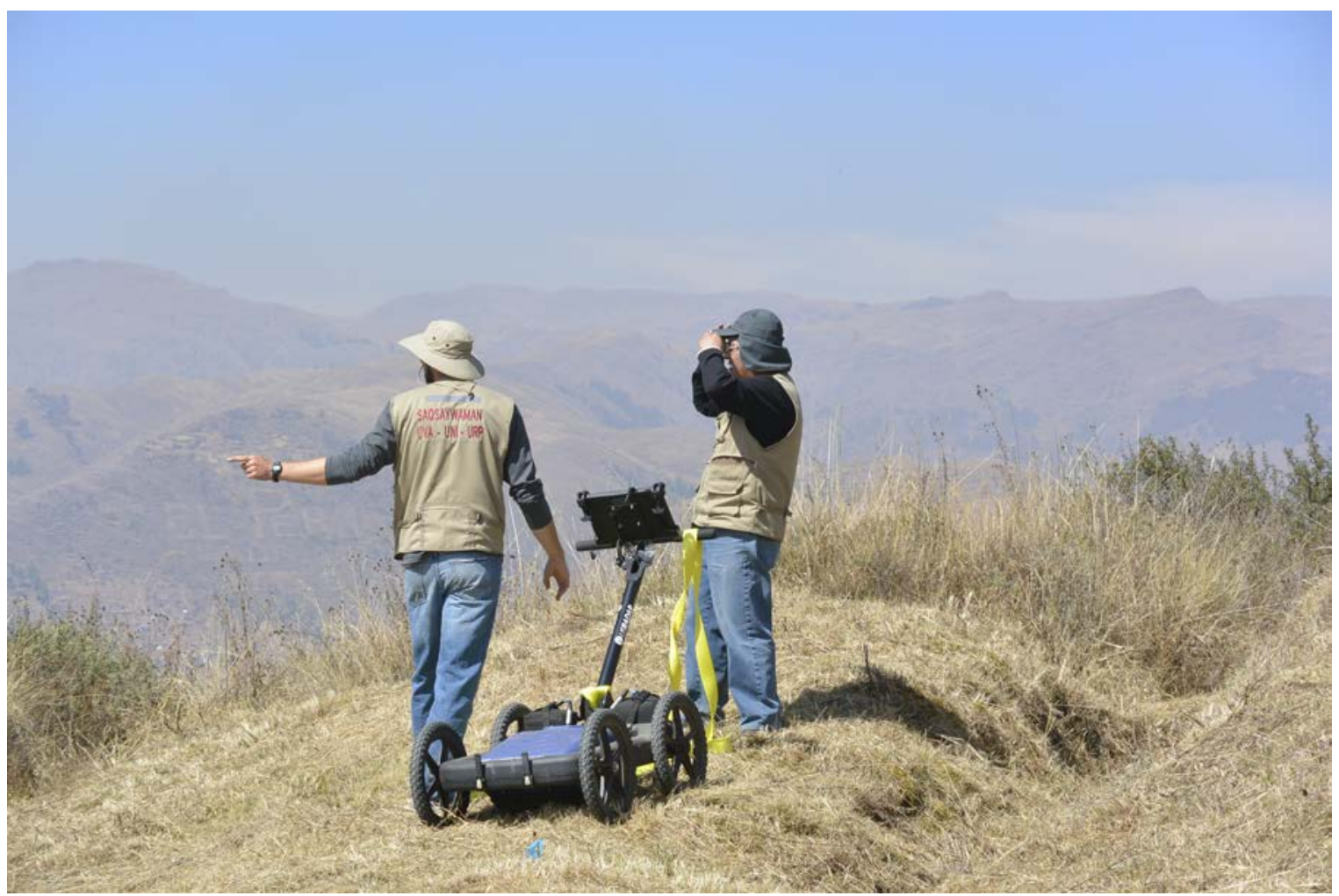

Figure 17: UVa and UNI engineers using the Quantum Imager to conduct GPR analyses at Saqsaywaman, 2015 [12]

The GPR system does have some basic limitations. Firstly, because it can only see interfaces under the soil, the nature of the object cannot truly be distinguished. A large rock appearing in several adjacent runs could be mistaken for a terrace. The GPR is also a very sensitive piece of equipment; if there is a rock one meter beneath the soil, the GPR will see it. In the case of Saqsaywaman, the 500 years of debris surrounding buried terrace walls may result in cluttered returns. Another 
significant limitation is dimensional inaccuracy due to poor resolution. The 3D strategy of aligning parallel runs has the obvious limitation of not having any information about what is occurring between adjacent surveys. Reducing the horizontal offset is an effective way of increasing the resolution, but it linearly increases the number of surveys that must be taken to plot the same ground area [16]. This increases the time it takes to survey an area, as well as complicates the above-ground grid that must be set up before survey can begin.

\section{Seismic Refraction Data Collection}

The Seismic Refraction analysis was conducted by the Seismic Refraction Team, consisting of UNI and RP engineers. Seismic refraction measurements are applicable in mapping subsurface conditions for various uses including geologic, geotechnical, hydrologic, and archaeological surveying. The seismic refraction method is used to map geologic conditions including depth to bedrock, water table, stratigraphy, lithology, structure, and fractures. Measurements of the travel time of a compressional (P) wave from a seismic source to a geophone are made from the land surface and are used to interpret subsurface conditions and materials. This travel time, along with distance between source and geophone, is interpreted to yield the depth to refracting layers. The calculated seismic wave velocity is related to the mechanical properties, so characterization of material is made on the basis of seismic velocity and other geologic information [2].

Similar to GPR, the primary goal of the Seismic Refraction team was to perform subsurface analyses at locations consistent with visual evidence of Inca terraces. The Seismic Refraction team used the SmartSeis ST, by Geometrics, for 2015 research. This seismograph included 24 geophones of $14 \mathrm{~Hz}$, as reported in the "Saqsaywaman Geophysical Report.” Results from these 
analyses were interpreted entirely by the Seismic Team and are summarized in this same report, found in Appendix A.

\section{Methods}

By overlaying the locations of the partially exposed terrace ruins and subsurface evidence of terraces on an aerial mage of Saqsaywaman, a trial terrace system could be established and the runoff patterns created by Inca terracing could be studied. In order to create this trial terrace system, there were two tasks to accomplish with the 2015 data. Task 1 was to use GPR data to document 2015 subsurface data collection. Task 2 was to plot all significant point features that represent evidence of Inca Terraces. After completing these tasks, Inca Terraces could be located and delineated based on the distribution of all significant point features. This work was completed using ArcGIS 10.3 and mapped with the UTM coordinate system.

\section{A. RAW DATA Format}

Each engineering instrument returned its own set of raw data. GPR, Seismic Refraction, and Total Station analyses delivered point files. In the case of GPR, one csv file is created per run taken on the site. Points within these files include attributes of point ID, Latitude (decimal degrees), Longitude (decimal degrees), Elevation (meters), and Point Description. A point ID of 0 indicates the beginning of a run, an ID of 1 indicates the end of a run, and all other point ID's represent points manually chosen as significant subsurface anomalies. Alternatively, the Total Station exports a csv file per project created by the user. Within each project, data points may have different descriptors that further categorize them. Points within these files include attributes of point ID, Northing, Easting, Elevation, and Description. Examples of the raw data output from

GPR and Total Station can be seen in Tables 2 and 3. Seismic Refraction data was processed and 
interpreted by engineer from UNI and RP. Seismic Refraction results were for each run taken within a table (see Table 4).

Table 2: GPR Raw Data Sample

\begin{tabular}{|r|r|r|r|l|}
\hline \multicolumn{1}{|c|}{ ID } & \multicolumn{1}{|c|}{ GPS_Latitude } & \multicolumn{1}{|c|}{ GPS_Longitude } & \multicolumn{1}{|c|}{ Real_Elevation } & Description \\
\hline 2 & -13.50942488 & -71.98142167 & 3620.883 & East Hill 8 \\
\hline 3 & -13.509385 & -71.981405 & 3619.89035 & East Hill 8 \\
\hline 0 & -13.50942667 & -71.98142167 & 3621.17502 & East Hill 8 \\
\hline 7 & -13.50922917 & -71.98132792 & 3617.14518 & East Hill 8 \\
\hline 8 & -13.50918357 & -71.98130762 & 3616.1444 & East Hill 8 \\
\hline 4 & -13.50936167 & -71.9814 & 3620.28508 & East Hill 8 \\
\hline 5 & -13.50932796 & -71.98137963 & 3619.5181 & East Hill 8 \\
\hline 1 & -13.50914833 & -71.9813 & 3615.19001 & East Hill 8 \\
\hline 6 & -13.509295 & -71.98136444 & 3619.52841 & East Hill 8 \\
\hline
\end{tabular}

Table 3: Total Station Raw Data Sample

\begin{tabular}{|r|c|c|r|l|}
\hline $\begin{array}{c}\text { Point } \\
\text { ID }\end{array}$ & Northing & Easting & $\begin{array}{c}\text { Real } \\
\text { Elevation }\end{array}$ & Name_Description \\
\hline 69 & 8504610.756 & 177234.8953 & 3590.6723 & Terrace Remains \\
\hline 70 & 8504610.075 & 177236.8436 & 3590.7366 & Terrace Remains \\
\hline 71 & 8504609.846 & 177238.1145 & 3590.492 & Terrace Remains \\
\hline 72 & 8504609.699 & 177239.3466 & 3590.2901 & Terrace Remains \\
\hline 73 & 8504609.351 & 177241.2601 & 3590.0217 & Terrace Remains \\
\hline 74 & 8504608.543 & 177242.6976 & 3589.9067 & Terrace Remains \\
\hline 75 & 8504607.778 & 177244.8104 & 3589.7007 & Terrace Remains \\
\hline 76 & 8504607.306 & 177245.9823 & 3589.7389 & Terrace Remains \\
\hline 103 & 8504596.318 & 177226.5077 & 3593.1202 & Terrace Remains \\
\hline 104 & 8504597.473 & 177220.693 & 3593.7193 & Terrace Remains \\
\hline
\end{tabular}




\section{B. AdDING DATA to AN ARcGIS MAP}

GPR and Survey data were imported to ArcGIS using the Add XY Data tool. This tool requires that columns of an input table be specified as $\mathrm{X}, \mathrm{Y}$, and $\mathrm{Z}$ fields. In the case of GPR files, "Longitude" and "Latitude" data were assigned to the X and Y fields, respectively. For survey files, "Easting” and "Northing” fields were assigned as X and Y. Both file types had a clearly designated Z field of "Real Elevation.” Given these specifications, points within input tables were converted into shape features ${ }^{1}$, belonging to a unique feature class for every data file. All feature classes were imported to a geodatabase, “2015Data.gdb.” Within this geodatabase feature classes were assigned to an appropriate feature dataset, either “GPR_Data” or "Survey_Data.”

After importing the files as feature classes into GIS, it was necessary to project all point features into the same projection. The projection chosen for this project was Universal Transverse Mercator (UTM) Zone 19 South, corresponding to the UTM Zone of Cusco. Survey data was already in the UTM coordinate system, so this step was only necessary for GPR data. Additionally, GPR data files contain a set of points for each run that include start/end points as well as subsurface anomalies. Including these start/end points of runs may have led to a clustering of points that do not truly indicate significant subsurface anamolies. For this reason, GPR data required the additional step of separating start/end points from anamoly points.

Due to the large quantity of subsurface data files, and the tedious nature of manually projecting features and separating specific points, these steps were automated using ArcPy, a Python module for executing ArcGIS geoprocessing tools. The Python script used to project from a global coordinate system to the appropriate UTM projection can be seen in Figure 18. This script consists

\footnotetext{
${ }^{1}$ In an ArcCatalog, a "Shape Feature Class" may contain feature classes of either polygon shapes or point features. The terms "shape feature" and "point feature" may be used interchangeably to refer to the imported point data.
} 
of a for-loop that iterated over each feature in all feature classes of a specified feature dataset. In Line 1, a feature dataset is selected as the working environemnt. In Line 2 a list of all feature classes were accessed with the arcpy.ListFeatureClasses command and named “Files.” Line 3 sets up the for-loop in which an action is performed on every shape feature, named "run,” contained in the list of "Files." Subseqeunt lines specify that each "run” is projected with certain parameters using the arcpy.Project_Management command. Output files are named as the original name, with a “_proj” extension. The newly projected point feature classes were redirected to a new feature dataset, named with the originial dataset name, with a “_proj” extension.

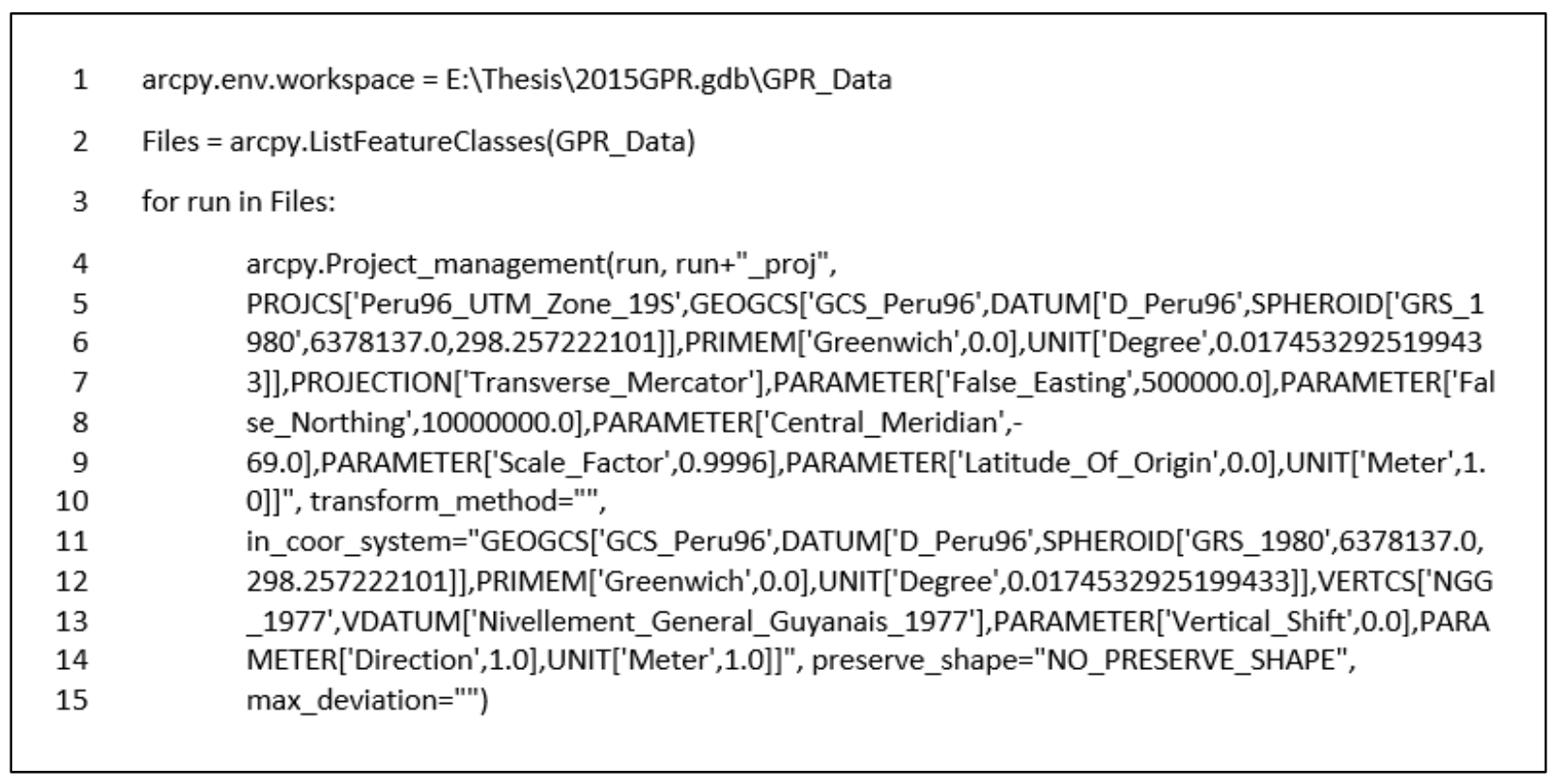

Figure 18: ArcPy Projection Script 
Another script was created to automate the separation process of GPR documented data. The working environment was changed to the projected feature dataset, and the list of all projected shape features was accessed as previously explained. Line 1 constructs another for-loop in which a conditional statement was applied to every "run" in "Files." The first conditional statement (Line 2) searched for points with a corresponding point ID equal to 0 or equal to 1 . A second conditional statement (Line 3) searched for points with a corresponding ID not equal to 0 and not equal to 1. Using the acrpy.Select_analysis command, points that met the first condition were selected and exported to a new file with a “_ends” extension. Alternatively, points meeting the second condition (all remaining points within the file) were selected and exported to a new file, with a “_anom” extension (Figure 19). All resulting files were designated to a new feature dataset within the global “2015Data” geodatabase.

$$
\begin{aligned}
& 1 \text { for run in Files: } \\
& 2 \text { arcpy.Select_analysis(run, run “_ends", where_clause="ID = } 0 \text { OR ID = 1") } \\
& 3 \text { arcpy.Select_analysis(run, run+"_sig", where_clause="ID }<>0 \text { AND ID }<>1 \text { ") }
\end{aligned}
$$

Figure 19: ArcPy Selection Script

\section{TASK 1: Documenting 2015 Subsurface Data Collection}

With all GPR documented data properly projected and organized, Task 1 could be addressed. Thoroughly documenting 2015 data called for mapping the location of each GPR and Seismic Refraction run. Recall, GPR runs included all Seismic Refraction runs so within the GPR data is location data for both GPR and Seismic Refraction. In addition to documenting locations, run lengths and slopes would also be calculated as a potential reference in the case that excavations take place as a result of this research. This was accomplished with another ArcPy script (Figure 
20). The working environment was specified as the feature datasets containing projected end points, 'GPR_ends'. In Line 1, a for-loop was created which applied GIS tools to every shape feature class within the feature dataset, referred to as "run" and "Files," respectively. First, arcpy.PointsToLine command creates a Line Feature that is drawn in sequential order, sorted by the point ID field (from point 0 to point 1 ). Each resulting Line Feature is saved to the original feature dataset, with a “_L” extension (Line 2). Next, elevation information was added to each feature with arcpy.AddZInformation (Line 4). With this tool new attributes were added to each line feature, based on the original x,y,z data of the point. Tables B1 and B2, found in the Appendix, summarize these new attributes for each line feature. Accompanying these tables are Figures B1 and B2, which show the GPR and Seismic Refraction labels, also in the Appendix. Figure 21 shows the combination of GPR and Siesmic Refraction runs and better illustrates the extent of 2015 subsurface data collection.

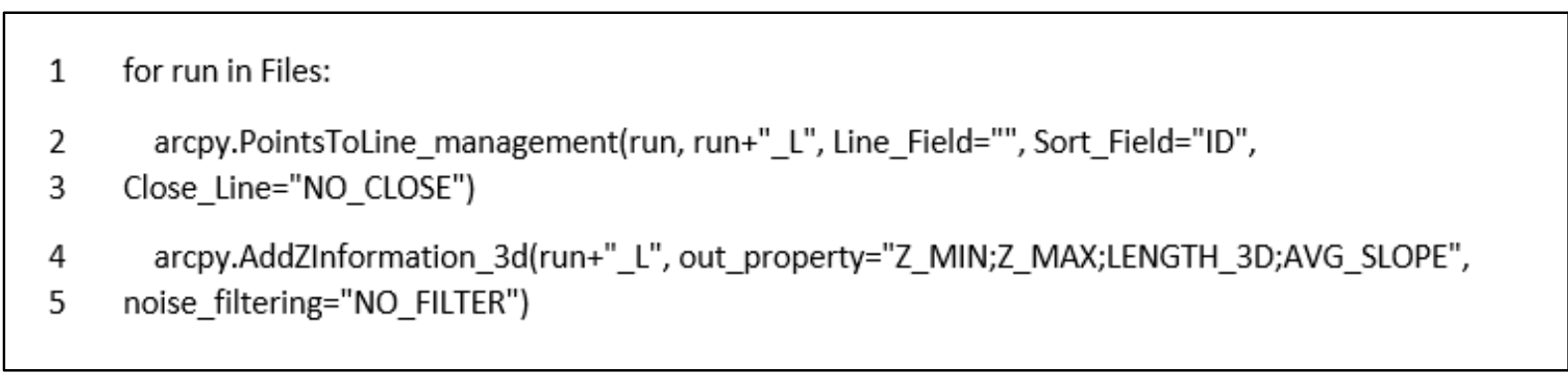

Figure 20: ArcPy Line Creation Script 


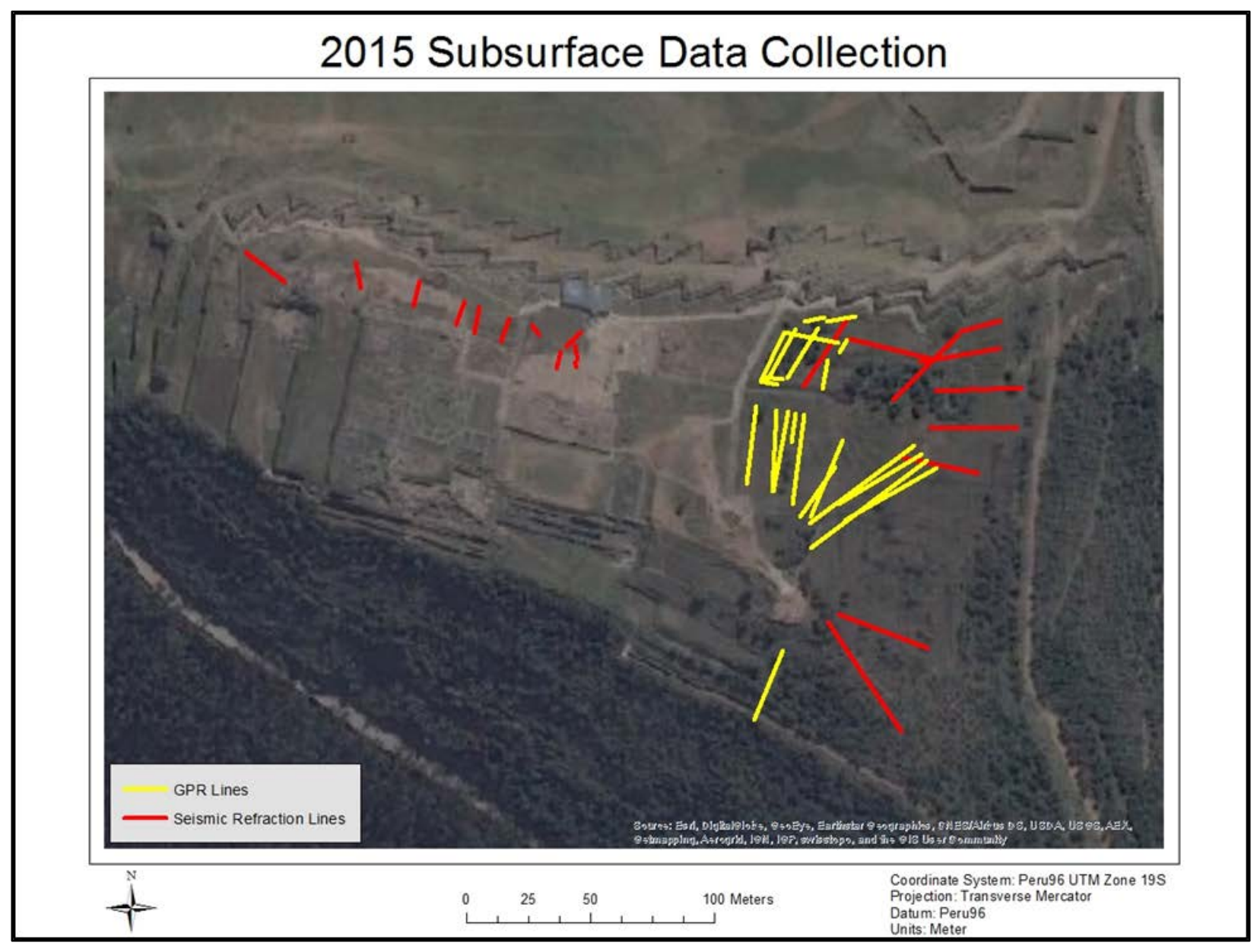

Figure 21: 2015 Subsurface Data Collection, documented with Quantum Imager GPR

\section{TASK 2: PLOTTING SIGNIFICANT POINTS}

To address Task 2, all point features representing evidence of Inca Terraces had to be plotted on a single site map. The first set of significant points was Total Station documented visual evidence. Survey data was collected for two types of significant points: Structural Remains and Terrace 
Remains. Structural Remains refer to small collections of exposed stone that may have been foundations of ancient structures or fragmented terrace remains (Figure 22).

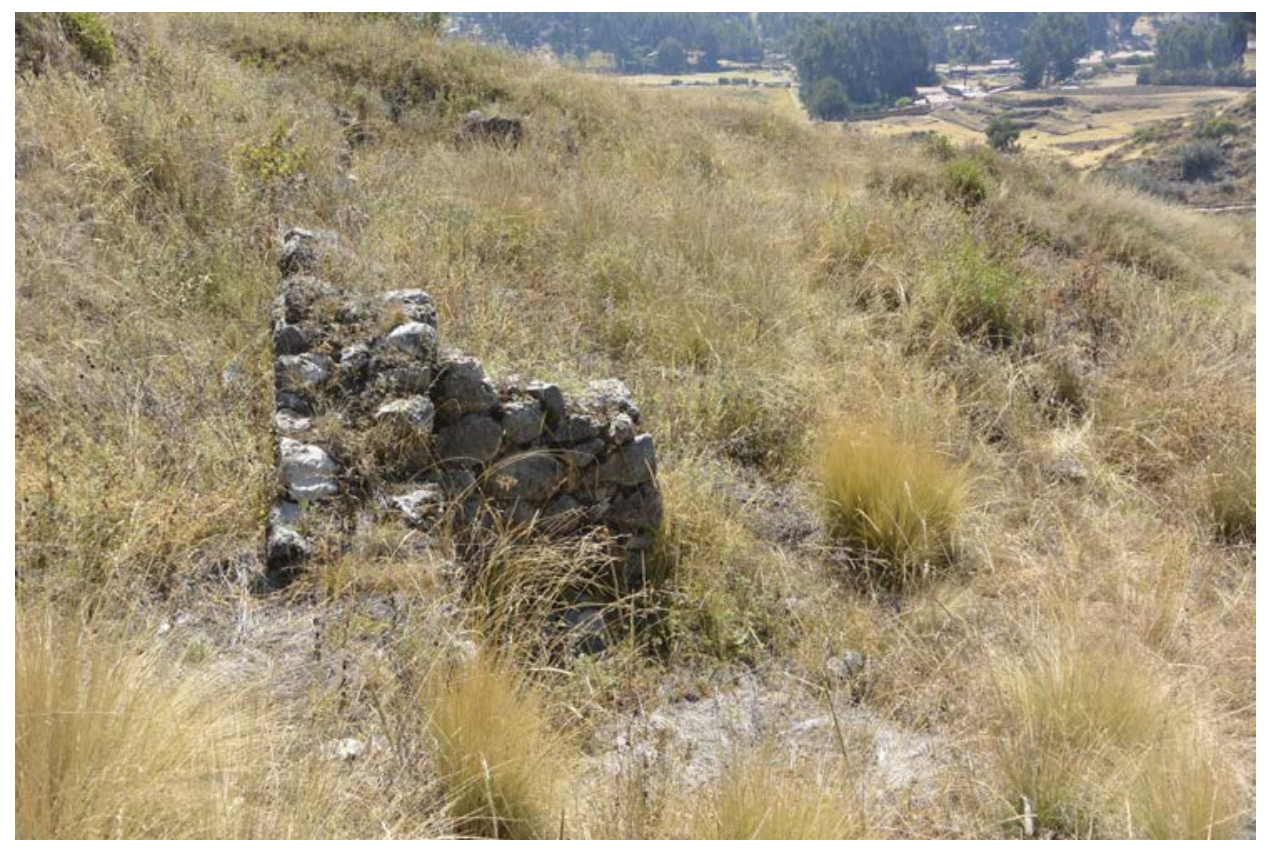

Figure 22: Example of Structural Remains at Saqsaywaman [12]

Terrace Remains refer to larger collections of exposed stone in a linear arrangement or to a sudden drop in elevation which indicates buried terraces (Figure 23).
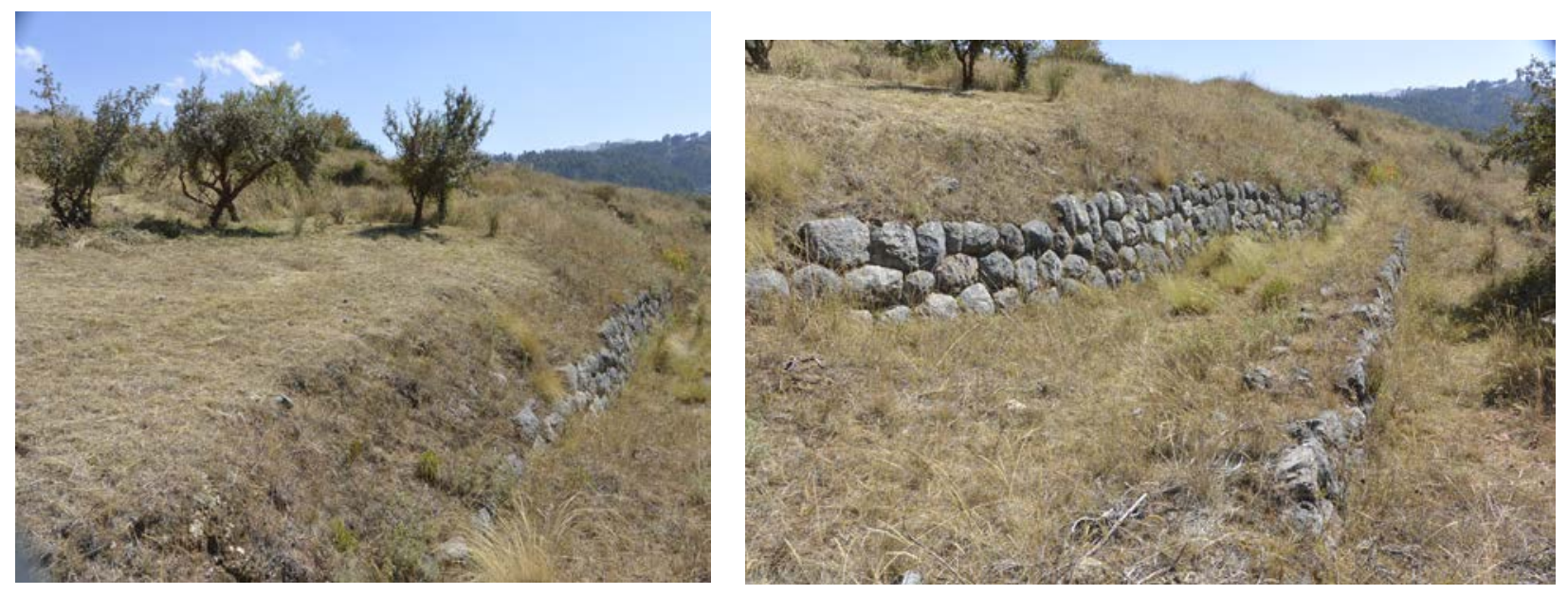

Figure 23: Example of Terrace Remains at Saqsaywaman. Left shows a buried terrace, Right shows exposed terrace wall [12] 
In addition to structural and terrace remains, existing terraces on the west side of the site were considered to be visual evidence (Figure 24). Survey data of these terraces were converted to line features and assigned elevation data with the same process as previously described. These line featues and their elevation data would be used as starting points for proposed Inca Terraces, with the assumption that Inca terraces typically follow contour lines and wrapped around the entirety of Inca sites. A GIS map displaing the categorized visual evidence can be seen in Figure 25.

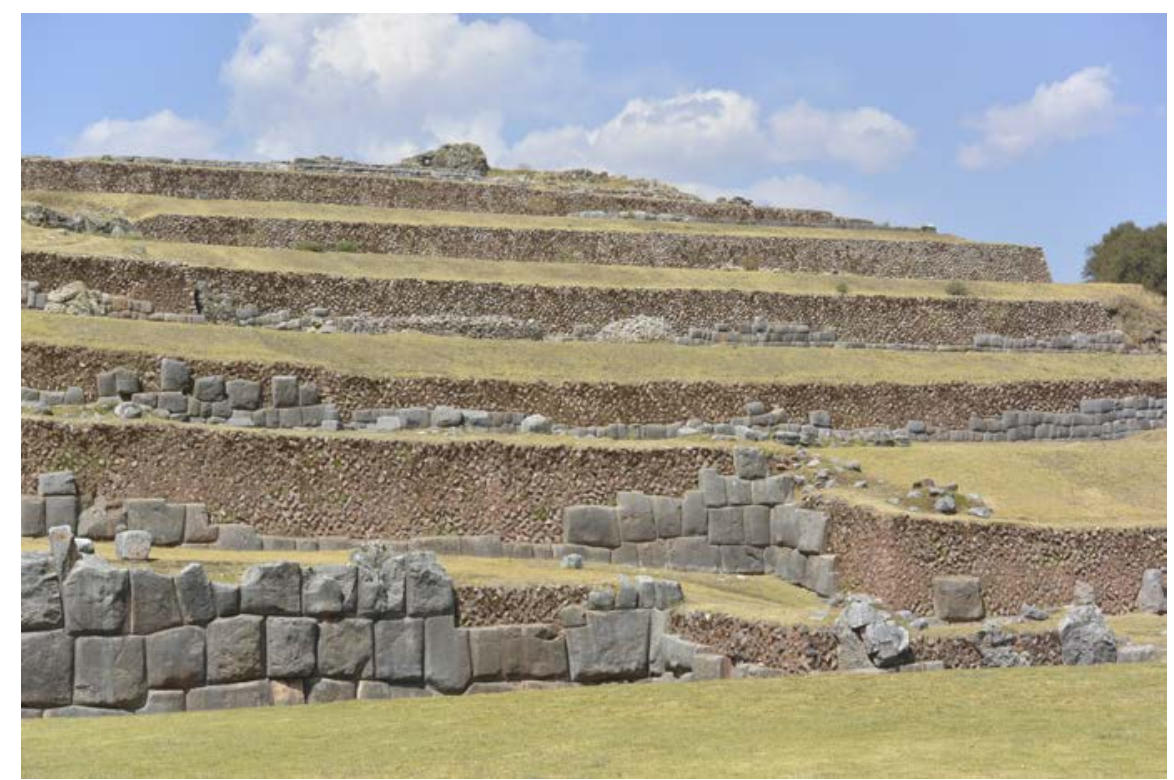

Figure 24: Existing Terraces on west side of Saqsaywaman [12]

It is possible that some strucutral remains represent fragmented portions of terrace remains, or that strucutral remains that indicate foundations of buildings may not be in their original location. Due 
to the ambiguity in the data, structural remains were subsequently merged together with terrace remains into a single 'Visual Evidence' shape feature class.

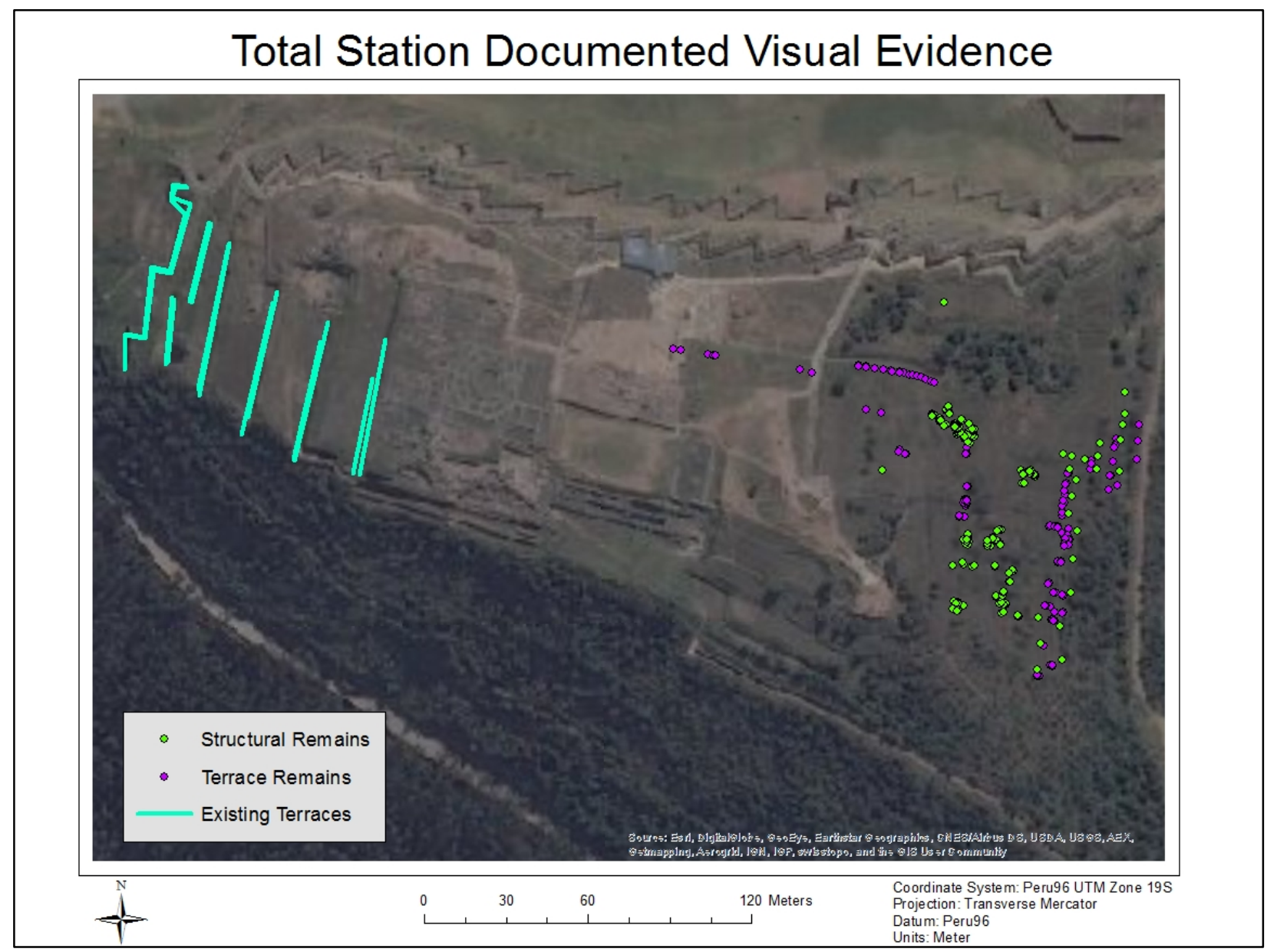

Figure 25: Map of visual evidence of Inca Terraces, as documented by Total Station

As previously stated, anomalies detected by Seismic Refraction analyses were summarized for each run in Table 4. In Table 4, an anomaly found along a run has a correspdoning distance from the run starting point at which the anomaly was found. The Seismic Refraction team also provided an acompanying figure indicating start points of each run (Figure 26). Another point feature class had to be created from the locations of these anomalies to complete Task 2. To do so, the seismic run referenced in Figure 26 was located in Figure B2 (Appendix), and the corresponding distance to anomaly from Table 4 was measured in ArcGIS. At this location, a point feature was created. 
This process was repeated for all reported anomalies in Table 4 and all point features were merged into a single feature class, "Seis_anom."

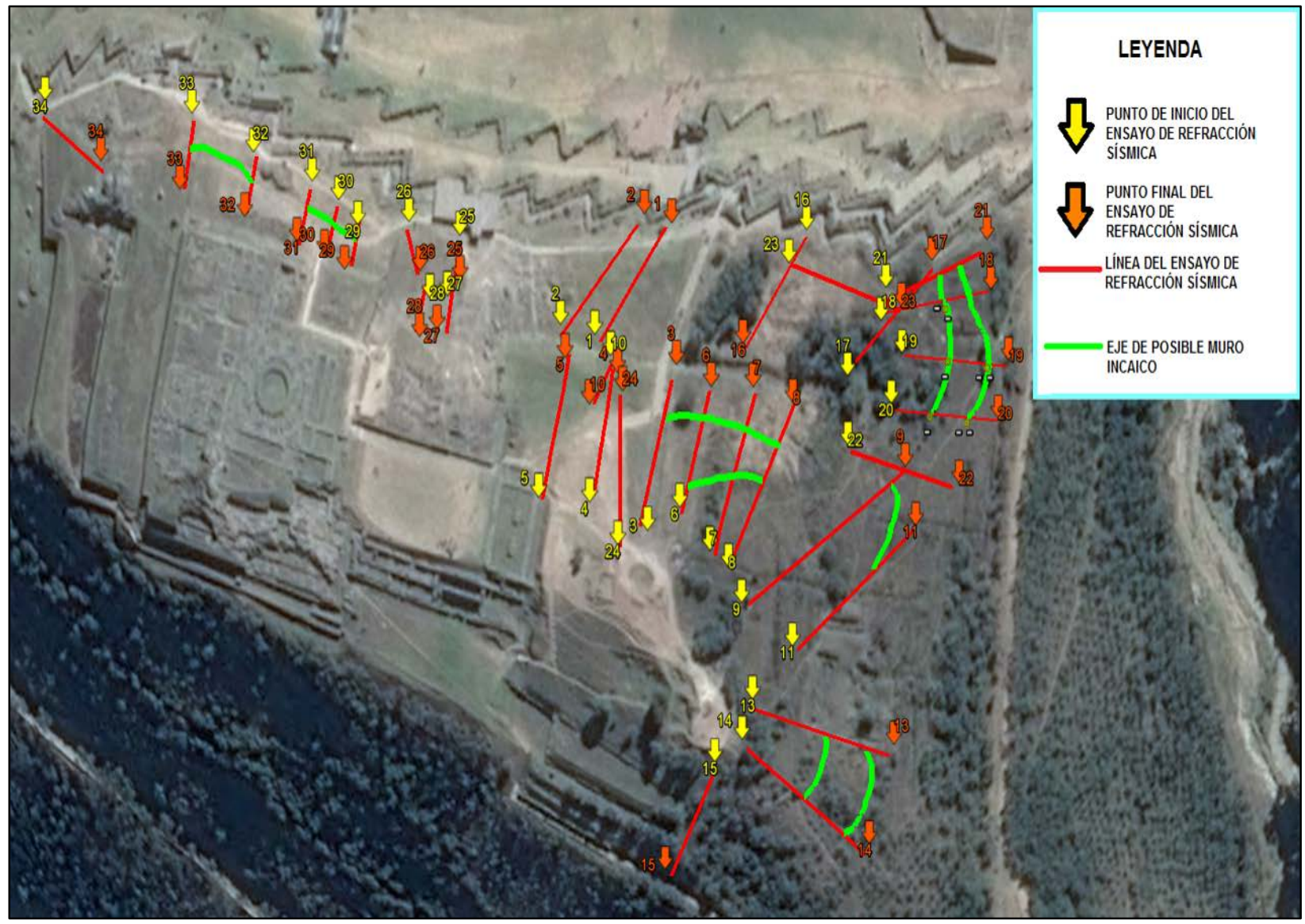

Figure 26: Seismic Run labels corresponding to Table 5, yellow arrow indicates start of run, orange arrow indicates end of run. Provided by "Saqsaywaman Geophysical Report" 
Table 4: Seismic Refraction Results, provided by "Saqsaywaman Geophysical Report"

\begin{tabular}{|c|c|c|c|}
\hline Run Name & $\begin{array}{l}\text { P Velocity } \\
{[\mathrm{m} / \mathrm{s}]}\end{array}$ & $\begin{array}{c}\text { Distance from beginning } \\
\text { of run [m] }\end{array}$ & Comment \\
\hline LS-01 & - & - & - \\
\hline LS-02 & - & - & - \\
\hline LS-03 & $500-600$ & $23.0 \mathrm{~m}$ & Evidence of Inca Terrace \\
\hline LS-04 & - & $30.0 \mathrm{~m}$ & - \\
\hline LS-05 & $500-600$ & $29.0 \mathrm{~m}$ & Evidence of Inca Terrace \\
\hline LS-06 & $500-600$ & $12.0 \mathrm{~m}$ & Evidence of Inca Terrace \\
\hline LS-07 & $500-600$ & $31.0 \mathrm{~m}$ & Evidence of Inca Terrace \\
\hline LS-08 & - & - & - \\
\hline LS-09 & $500-600$ & $54.0 \mathrm{~m}$ & Evidence of Inca Terrace \\
\hline LS-10 & $500-600$ & $5.0 \mathrm{~m}$ & Evidence of Inca Terrace \\
\hline LS-11 & $500-600$ & 29.0m & Evidence of Inca Terrace \\
\hline LS-12 & - & - & - \\
\hline LS-13 & $\begin{array}{c}450-700 / 700- \\
900\end{array}$ & $22.0 \mathrm{~m} / 38.0 \mathrm{~m}$ & Evidence of Inca Terrace \\
\hline LS-14 & $\begin{array}{c}450-700 / 700- \\
900\end{array}$ & $8.0 \mathrm{~m} / 23.0 \mathrm{~m} / 40.0 \mathrm{~m}$ & Evidence of Inca Terrace \\
\hline LS-15 & - & - & - \\
\hline LS-16 & - & - & - \\
\hline LS-17 & $500-650$ & $13.0 \mathrm{~m}$ & Evidence of Inca Terrace \\
\hline LS-18 & $500-700$ & $19.5 \mathrm{~m} / 30 \mathrm{~m}$ & Evidence of Inca Terrace \\
\hline LS-19 & $450-550$ & $1.0 \mathrm{~m} / 14.0 \mathrm{~m} / 28.0 \mathrm{~m}$ & Evidence of Inca Terrace \\
\hline LS-20 & $500-600$ & $11.0 \mathrm{~m} / 26.0 \mathrm{~m}$ & Evidence of Inca Terrace \\
\hline LS-21 & $500-600$ & $15.0 \mathrm{~m} / 25.0 \mathrm{~m}$ & Evidence of Inca Terrace \\
\hline LS-22 & 450 & $1.0 \mathrm{~m}$ & Evidence of Inca Terrace \\
\hline LS-23 & 450 & $6.0 \mathrm{~m} / 28.0 \mathrm{~m}$ & Evidence of Inca Terrace \\
\hline LS-24 & - & - & - \\
\hline LS-25 & $700-1200$ & $4.5 \mathrm{~m}$ & Evidence of Inca Terrace \\
\hline LS-26 & $700-1200$ & $6.0 \mathrm{~m}$ & Evidence of Inca Terrace \\
\hline LS-27 & $500-700$ & $5.6 \mathrm{~m} / 9.5 \mathrm{~m}$ & Evidence of Inca Terrace \\
\hline LS-28 & 500 & $5.0 \mathrm{~m}$ & Evidence of Inca Terrace \\
\hline LS-29 & $500-700$ & $4.0 \mathrm{~m}$ & Evidence of Inca Terrace \\
\hline LS-30 & $500-600$ & $5.0 \mathrm{~m} / 8.0 \mathrm{~m}$ & Evidence of Inca Terrace \\
\hline LS-31 & 700 & $5.0 \mathrm{~m}$ & Evidence of Inca Terrace \\
\hline LS-32 & $700-900$ & $4.5 \mathrm{~m}$ & Evidence of Inca Terrace \\
\hline LS-33 & $700-900$ & $3.5 \mathrm{~m}$ & Evidence of Inca Terrace \\
\hline LS-34 & $700-900$ & $4.0 \mathrm{~m} / 15.0 \mathrm{~m}$ & Evidence of Inca Terrace \\
\hline
\end{tabular}


In the case of GPR detected anomalies, all point features in the "GPR_anom" feature class represent subsurface anomalies, so they were directly added to a site map. Finally, the "Visual Evidence" feature class and "Seis_anom" feature class were added to this GIS map to reflect all collected evidence of Inca Terraces (Figure 27).

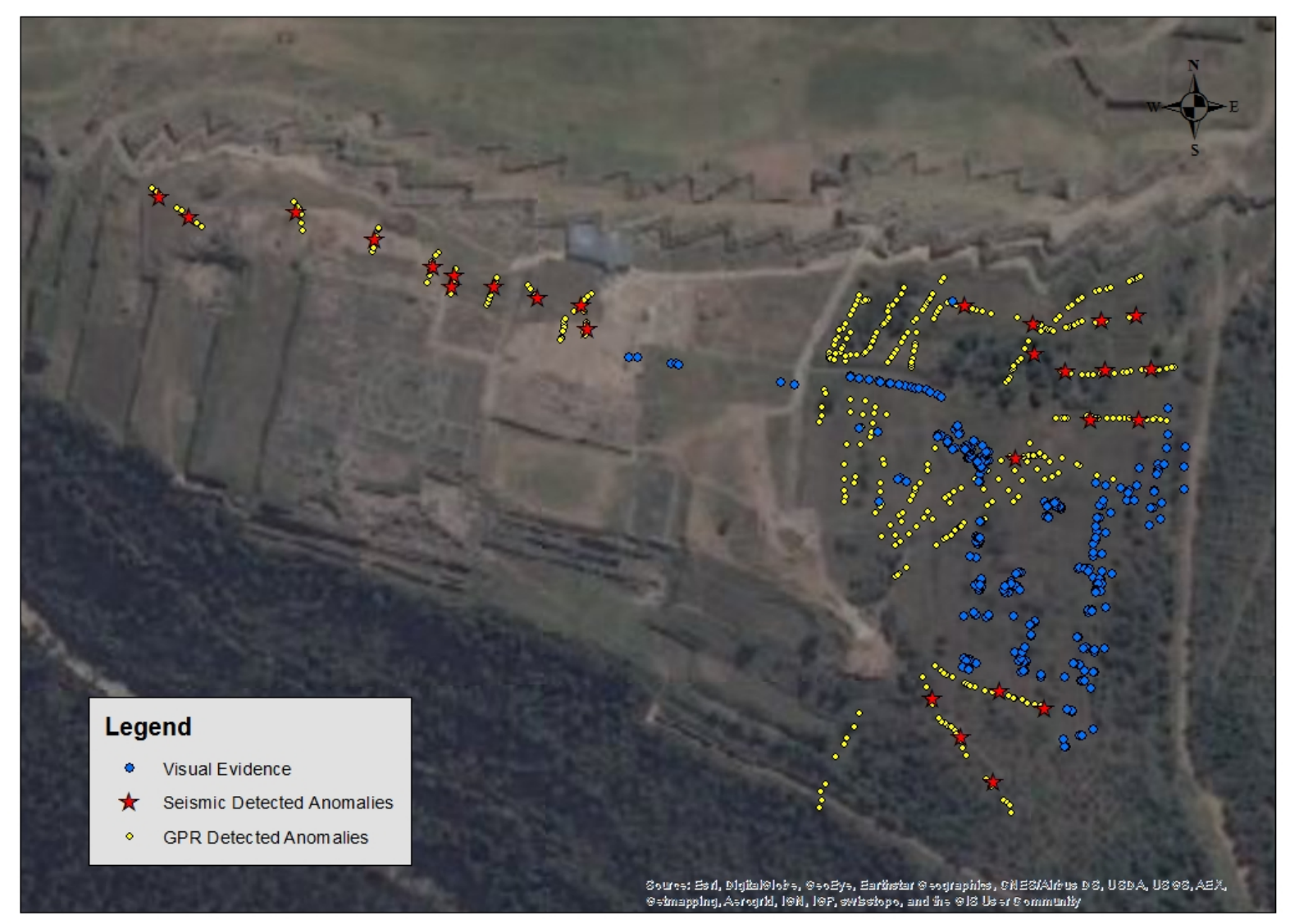

Figure 27: All Collected Evidence of Inca Terrace Location 


\section{RESULTS}

\section{A. INTERPRETING 2015 DATA TO LoCATE INCA TERRACES}

Using only the data and assumptions presented here, the location of Inca Terraces were best determined to be in the arrangement shown in Figure 28.

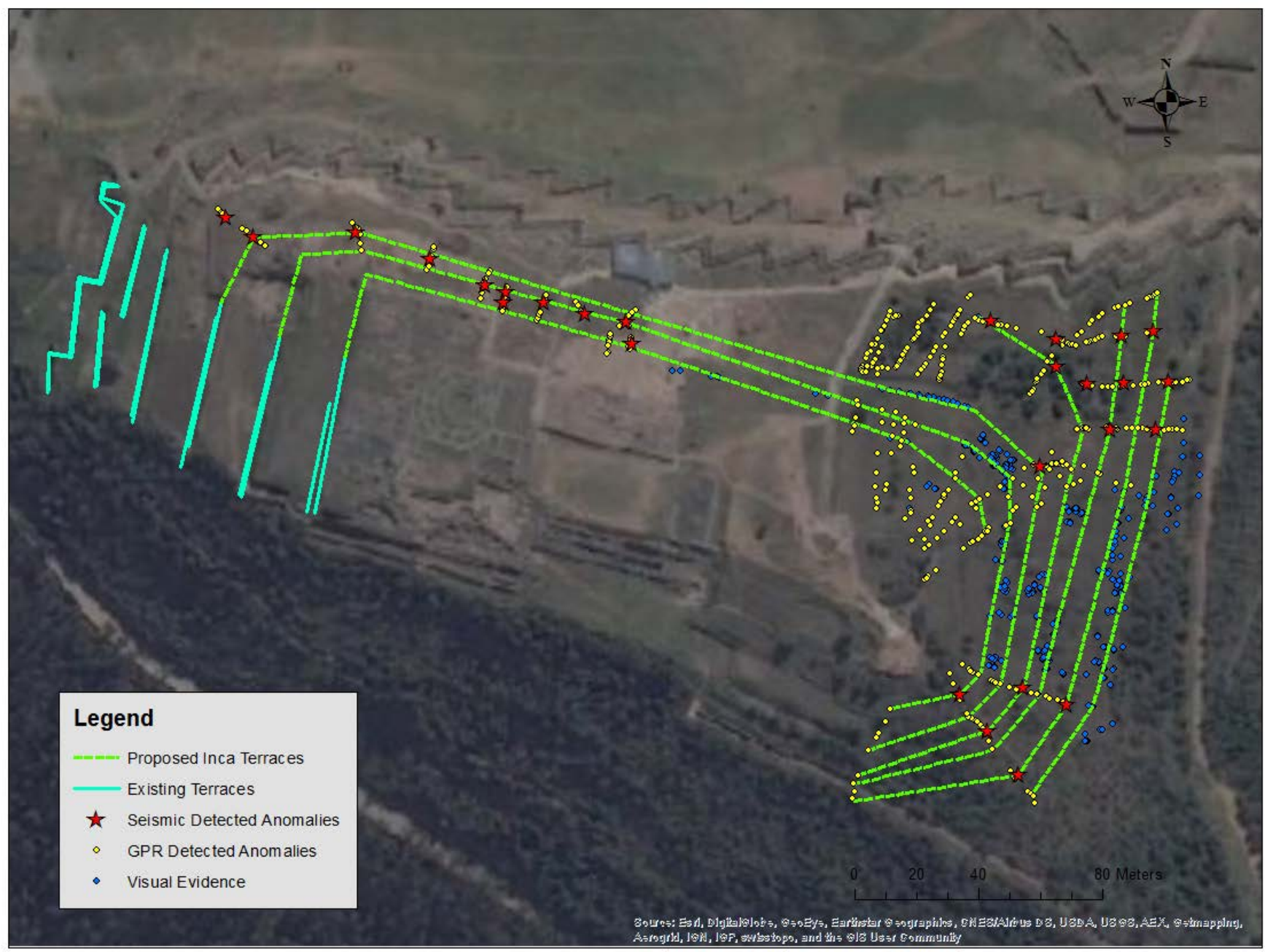

Figure 28: Inca Terrace Configuration based on 2015 Data Collection

Figure 29 shows all proposed Inca Terraces (labeled T1-T7) as well sections (A-E) that highlight important areas. Terraces were drawn in ArcGIS by creating new line featuers and snapping to significant points. When drawing in proposed terraces, there was a high priority to snap lines to points of agreement between any three of the sets of data. Visual evidence represented physical 
evidence of ruins so these points served as guidelines for including or excluding subsurface data. In Section A, Terraces 5, 6, and 7 were chosen to begin at the corners of existing terraces. The existing terraces are presently well defined and if assumed to be at a similar topgraphy to that of time of original construction, the starting elevations of Terraces 5, 6, and 7 are good approximations for Inca-era elevations. These terraces were further delineated by snapping to Seismic Refraction anomalies that overlapped with GPR anomalies, in Section B. Defining the curves along T5, T6, and T7 in Section C was guided by the Visual Evidence pattern which also overlapped GPR anomalies. The start and end of Terraces 1-4 was guided by the agreement between Seismic Refraction and GPR anomalies in Sections D and E. One may notice that T1, T2, and T3 are unique in that they do not curve upon meeting the north side of the site. It is plausible that these terraces could have merged into drainage channels at the corners of the Great Walls.

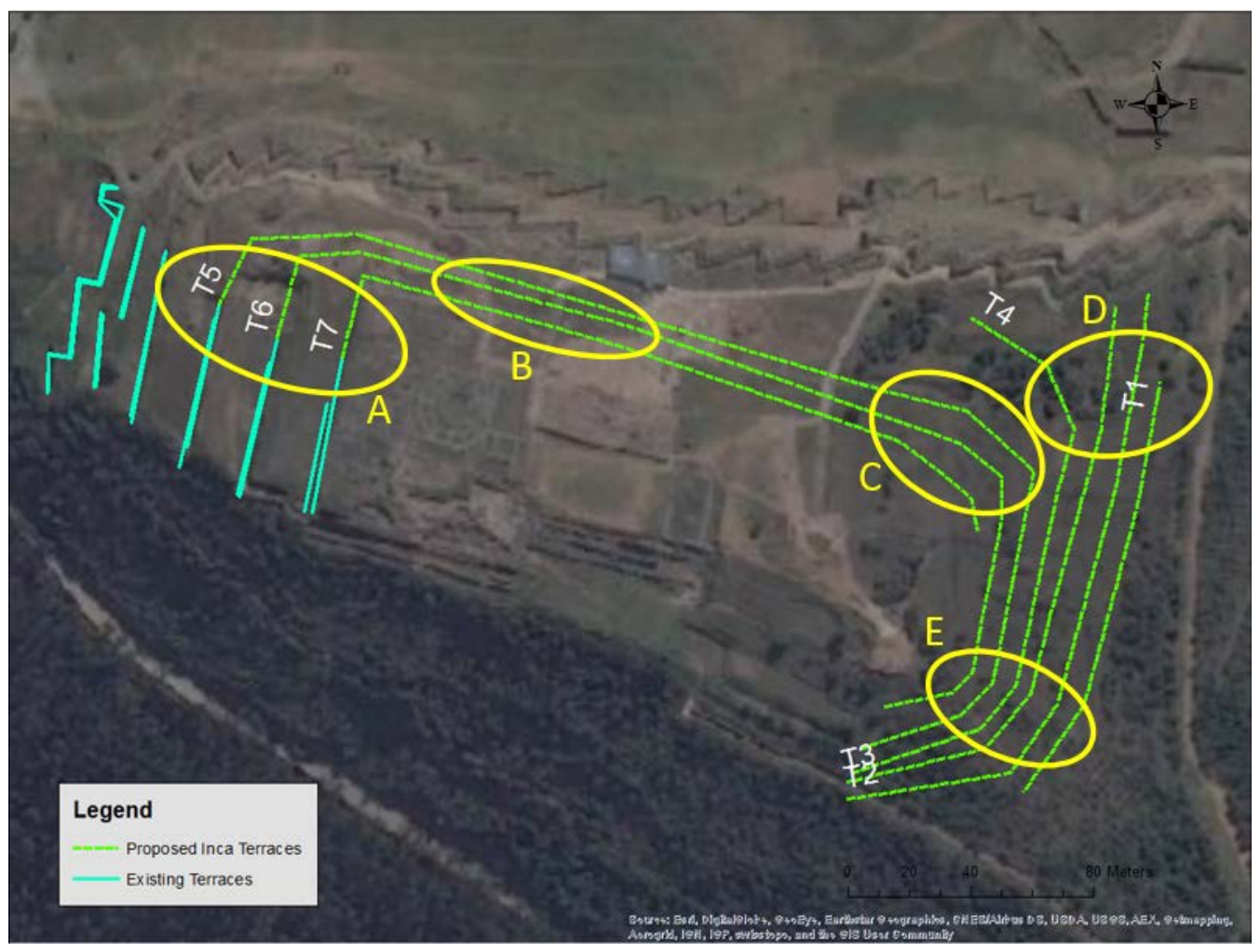

Figure 29: Labeled Proposed Inca Terrace Configuration 
The proposed terrace configuration in Figure 28 can only be validated through archeological research. While the proposed terrace is only a first approximatioin of the original Inca terracing, the research on which it is based makes it a worthwhile foundation for future work.

\section{B. The Role of a Cohesive Terrace System in Managing Runoff at Saqsaywaman}

If this terracing system features the previously stated key attributes, it would be considered a hydrologically sophisticated system. First, the grade of the terraces would channel runoff water to either the southeast or southwest corners of the site. Second, water flows laterally along terraces via base channels. Third, water only flows from one terrace to the next by controlled drops.

Assuming the proposed terraces met these three conditions, runoff would be efficiently diverted away from the Great Walls as shown in Figure 30. As shown, runoff would travel laterally along north facing terraces, flowing either east or west based on dividing location proposed by Lohr [11]. Upon reaching the turns at the starred locations, runoff would cross onto subsequent terraces through controlled drops, like those discussed in Tipon or Ollantaytambo. Runoff would continue to travel laterally along the bases of north-south running terraces until reaching some drainage outlet in the southeast or southwest corners of the site. 


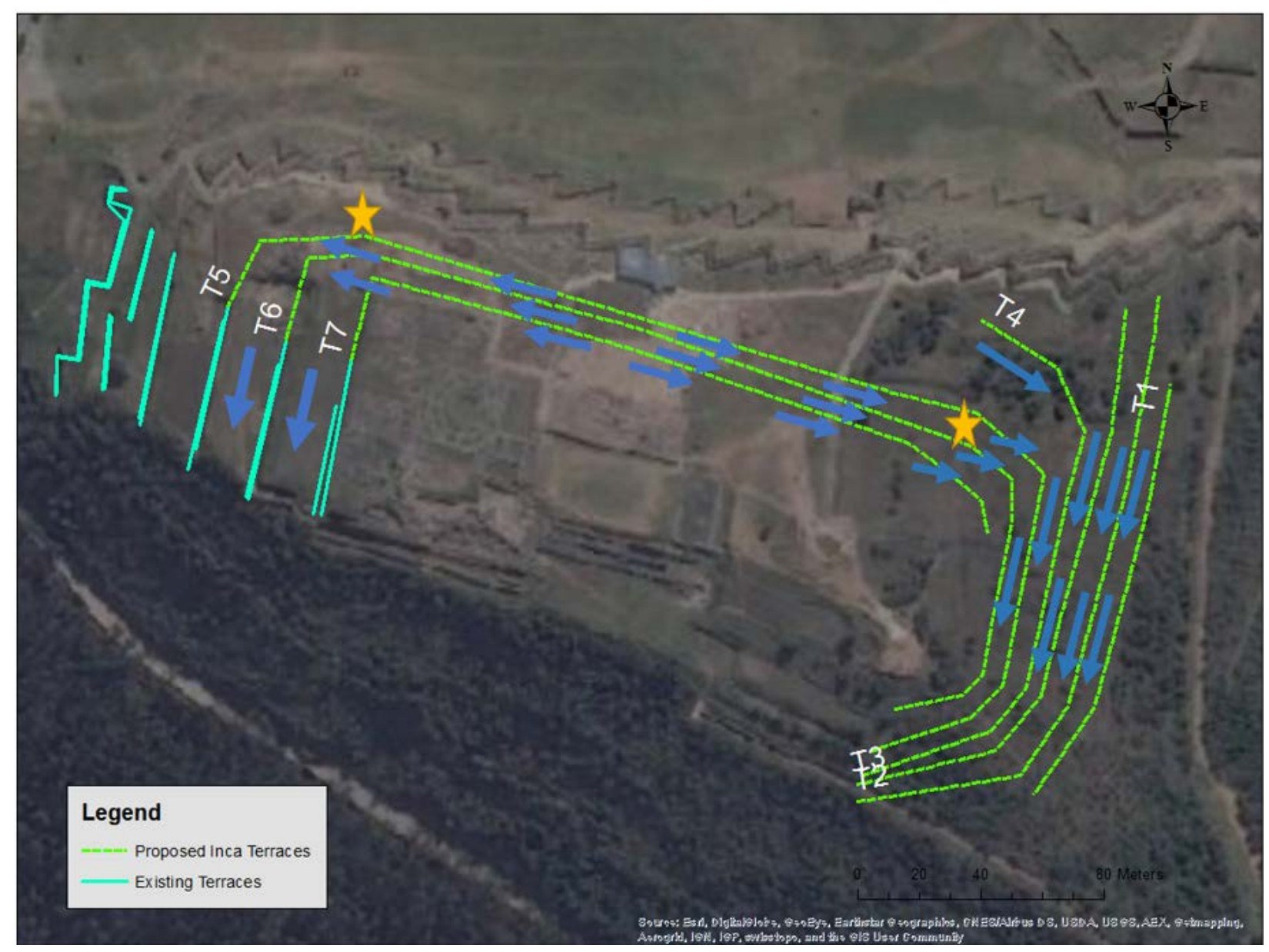

Figure 30: Flow patterns resulting from implementation of Inca Terrace Configuration

\section{CONCLUSIONS}

Several important conclusions can be drawn from this study. First, there is strong evidence that Saqsaywaman was originally constructed with a hydrologically sophisticated terracing system that protected the Great Walls from uncontrolled runoff. Typical features of Inca architecture at Tipon, Ollantaytambo, and Suchana support this claim. These features are consistent with visual and subsurface evidence of a comprehensive terracing system at Saqsaywaman.

Second, this work demonstrates that the proposed terrace configuration is capable of managing runoff in a way that protects the Great Walls and the entire site from further degradation. However, 
this terracing system needs to be further validated with an archeological evaluation and a quantitative runoff analysis. Given the cultural importance of Saqsaywaman, any changes to the site must be thoroughly justified. The study presented here, although based on sound engineering analysis, should not result in work that in any way diminishes the historical integrity of the site.

\section{RECOMMENDATIONS}

There are two major recommendations for the continuation of the effort to protect Saqsaywaman from uncontrolled runoff.

First, a quantitative analysis of runoff resulting from the proposed terrace configuration should be performed. In order to assess the maximum volume of runoff managed by this system, the analysis should incorporate terrace base channels with dimensions and grades consistent with those found at other Inca sites. The purpose of this analysis should be to justify further archeological validation and any potential excavation that may be undertaken to uncover and restore Inca Terraces.

Second, the results of the GPR analysis should be revisited. When the original GPR returns are once again made available to UVa team members, a stricter criteria should be applied when selecting anomalies significant to this study. This criteria may be a size of hyperbola resulting from obstructions or a depth to obstruction that reflects a feasible depth to terrace remains only. Re-selecting GPR anomalies that meet stricter criteria such as these would result in fewer but more indicative significant points. Delineating an Inca Terrace system based on agreement between higher quality points would provide a stronger argument for the existence of buried Inca Terraces. 


\section{ReFERENCES}

[1] Andean Travel. (2015). Andean travel web 2011 peru photos. Retrieved April 4, 2016, fromhttp://www.andeantravelweb.com/peru/gallery/photos_best_of_cusco_peru.html

[2] ASTM Standard D5777. (2011). Using the seismic refraction method for subsurface investigation. West Conshohocken, PA: ASTM International.

[3] Benjumea, B., Teixido, T., \& Pena, J. A. (2001). Application of the CMP refraction method to an archaeological study (los millares, alermia, spain). Journal of Applied Geophysics, 46, 77-84.

[4] Conyers, L. B. (2013). Ground-penetrating radar. Ground-penetrating radar for archaeology (pp. 131-159) Altamira Press.

[5] Dean, C. (2010). A culture of stone. inka perspectives on rock. (pp. 143-179). Santa Cruz, CA: Duke University Press.

[6] Gasparini, G., \& Margolies, L. Inca architecture (P. J. Trans.). Bloomington, IN: Indiana University Press.

[7] GTS-240NM series total station (2011). Livermore, CA: Topcon Corporation.

[8] Hyslop, J. (2014). Inka settlement planning. Austin, TX: University of Texas Press.

[9] Imai, T., Sakayama, T., \& Kanemori, T. (1987). Use of ground-probing radar and resistivity surveys for archaeological investigations. Geophysics, 52, 137-150.

[10] Kauffman, H. W., \& Kauffman, J. E. (2012). Fortifications of the incas: 1200-1531. Fortress (). New York, NY: Osprey Publishing.

[11]Lohr, K. S. (2014). Restoring and preserving the incan cultural wonder of saqsaywaman. (Masters of Science, University of Virginia).

[12] Miksad, R. (Photographer) (2015). [Digital]

[13] Quantum imager quick start guide (2015). US Radar Inc.

[14] Salcedo, J. (2014, Sacsayhuaman en peligro por hundimiento de base de muros por filtraciones. La Republica, Retrieved from http://arepublica.pe/15-08-2014/sacsayhuaman-en-peligro-por-hundimiento-debase-de-muros-por-filtraciones

[15] Tsokas, G. N., Papazachos, C. B., Vafidis, A., Loukoyiannakis, M. Z., Vargemezis, G., \& Tzimeas, K. (1995). The detection of monumental tombs buried in tumuli by seismic refraction. Geophysics, 60(6), $1735-1742$.

[16] US radar software manual(2014). US Radar Inc.

[17]Wildfire, L., Miksad, R.W., Perez, A., Culotti, A., Beckman, E., Vranich, A., \& Wright, K.L. (2011). A paleo-hydrologic analysis of rainfall-runoff and drainage of the incan ruins of saqsaywaman, cusco, peru. 


\section{APPENDICES}

\section{A. SaQsaywaman GeOPHYSicAl Report}

The following report summarizes the conclusions drawn from the Seismic Refraction analysis at Saqsaywaman in 2015. The document was written by Alvaro Javier (UNI), Carmen Ortiz (UNI), Jorge Soto (UNI), Frank Rojas (RP), and Jose Galindo De La Cruz (RP).

\section{INFORME PRELIMINAR DE ENSAYOS GEOFÍSICOS EN EL PARQUE ARQUEOLÓGICO DE SAQSAYWAMAN}

\subsection{GENERALIDADES}

En los últimos años la Escuela de Ingeniería y Ciencias Aplicadas de la Universidad de Virginia ha realizado investigaciones sobre la causa de las fallas estructurales en las murallas de Saqsaywamán, llegando a la conclusión que el enfoque más efectivo y sostenible para proteger las murallas es restaurar los andenes originales.

Para cumplir este objetivo de lograr la restauración original del Parque Arqueológico de Saqsayhuamán la Universidad de Virginia ha solicitado la participación de la Universidad Nacional de Ingeniería y de la Universidad Ricardo Palma.

Para esta investigación se realizaron 181 líneas de investigación geofísica, en el anexo I y II se muestra los mapas de ubicación de estas líneas. De los cuales se ha utlizado 34 pares de líneas geofisicas para realizar la comparacion entre ambos ensayos lo que permitió estimar la estratigrafía del subsuelo en forma indirecta y encontrar posibles andenes y drenes enterrados en la zona de estudio.

\subsection{Objetivo}

Evaluar en funcion a la velocidad de ondas compresionales la ubicación de posibles andenes y drenes enterrados en la zona de estudio perteneciente al Parque Arqueológico de Saqsaywamán.

\subsection{Ubicación}

La zona de estudio denominado parque Arqueológico de Saqsaywaman se ubica al norte de la ciudad del Cusco se localiza en el distrito Cusco, provincia de Cusco, departamento de Cusco. El área total del terreno aproximada es de 22,729.17 m2.

Para llegar a la zona se utiliza la carretera asfaltada Cusco-Saqsaywaman- Pisaq cuya altitud varia de 3577 msnm a 3587 msnm ) 

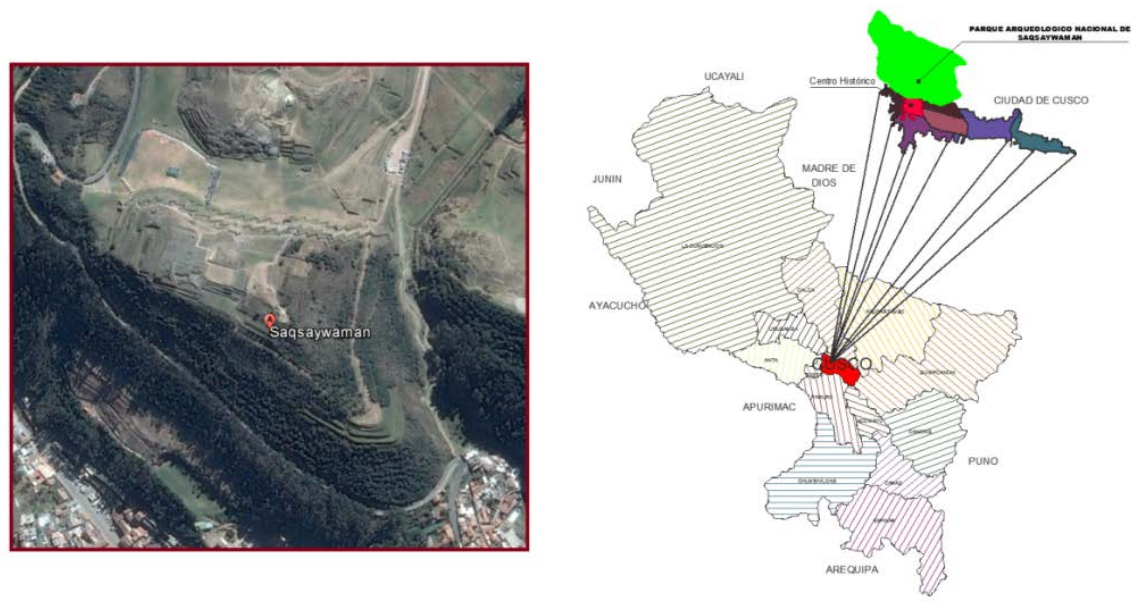

Imagen Nº1. Vista del Área de Estudio (fuente: Google Earth)

\subsection{INVESTIGACION GEOFISICA}

Con la finalidad de complementar los ensayos realizados con Georadar, se realizó una investigación geofísica.

La investigación geofísica consistió en la exploración del terreno ejecutándose 34 líneas con una longitud total de 1007 metros de líneas de refracción sísmica, mediante los cuales se determinaron las velocidades de ondas compresionales (Ondas $\mathrm{P}$ ), definiéndose la potencia de los estratos que conforman el terreno sobre el que se encuentra el Parque Arqueológico de Saqsaywamán .

\subsection{Ensayo Geofísico con Georadar}

Se trata de un método de prospección geofísica basado en la emisión de impulsos electromagnéticos de corta duración en la banda de frecuencias de UHF-VHF (entre $20 \mathrm{MHz}$ y $2.5 \mathrm{GHz}$ ). Gracias a un transmisor, se genera un tren de impulsos, es decir, de ondas EM que, al atravesar diferentes capas del subsuelo, provoca una reflexión de parte de la energía del frente de onda. El receptor detecta entonces estas reflexiones, generando un registro oimagen bidimensional "profundidad-distancia" del subsuelo, a lo largo de toda la línea de desplazamiento de la antena.

El Georadar, es una técnica no destructiva que permite realizar una exploración del subsuelo en superficie mediante la emisión de pulsos electromagnéticos. Cuando el pulso electromagnético de poca duración (nanosegundos) emitido por la antena transmisora atraviesa la superficie sufre reflexiones al incidir sobre interfaces u objetos con diferentes propiedades electromagnéticas, esta onda de regreso es captada por la antena receptora. Bajo un mismo punto de observación se tendrá un conjunto de reflexiones que constituirán una traza, al desplazar las antenas sobre la superficie van detectando y almacenando un conjunto de trazas en la línea de desplazamiento de las antenas, de esta forma se van formando una especie de "radiografía" del subsuelo, a la que se le denomina radargrama. 


\subsection{Ensayo de Refracción Sísmica}

El ensayo de refracción sísmica es un método de exploración geofísica que permite determinar la estratigrafía del subsuelo en forma indirecta, basándose en el cambio de las propiedades dinámicas de los materiales que lo conforman. Este método consiste en la medición de los tiempos de viaje de las ondas compresionales (Ondas P) y algunas veces de las ondas de corte (Ondas S) generadas por una fuente de energía impulsiva a unos puntos localizados a distancias predeterminadas a lo largo de un eje sobre la superficie del terreno (Gráfico $\mathrm{N}^{\circ} 01$ ).

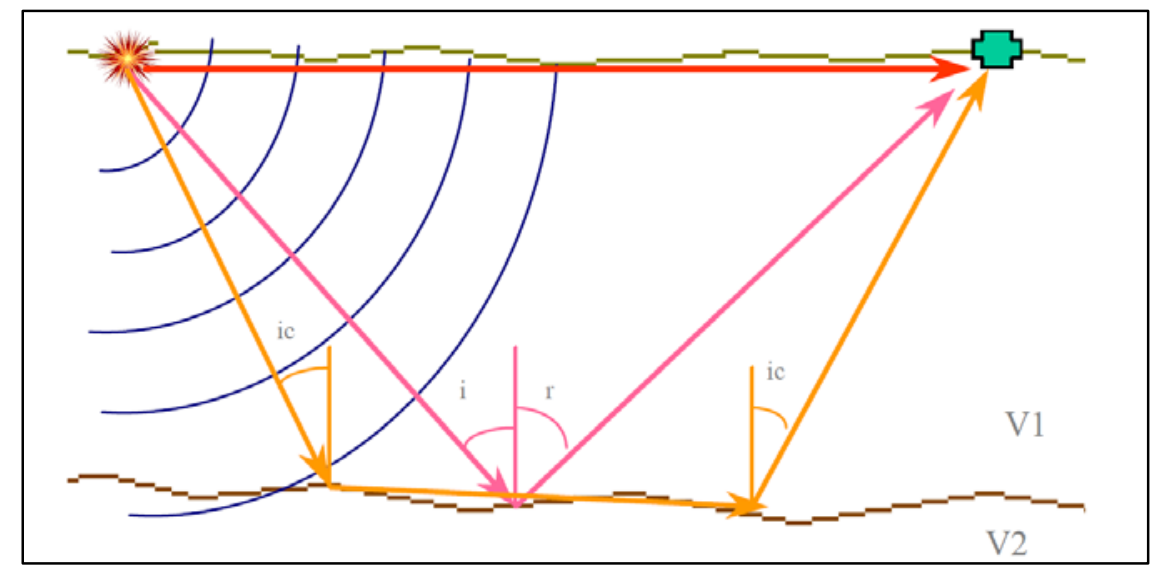

Gráfico $N^{\circ}$ 01: Refracción de las ondas sísmicas

La energía que se propaga en forma de ondas, es detectada, amplificada y registrada de tal manera que puede determinarse su tiempo de arribo en cada punto. El tiempo cero o inicio de la grabación es generado por un dispositivo de arranque o "trigger" que activa el sistema de adquisición de datos al momento de producirse el impacto o explosión. La diferencia entre el tiempo de arribo y el tiempo cero permite evaluar el tiempo de propagación de las ondas desde la fuente de energía hasta el lugar en que éstas son registradas, como se aprecia en la Gráfico $\mathrm{N}^{\circ} 02$.

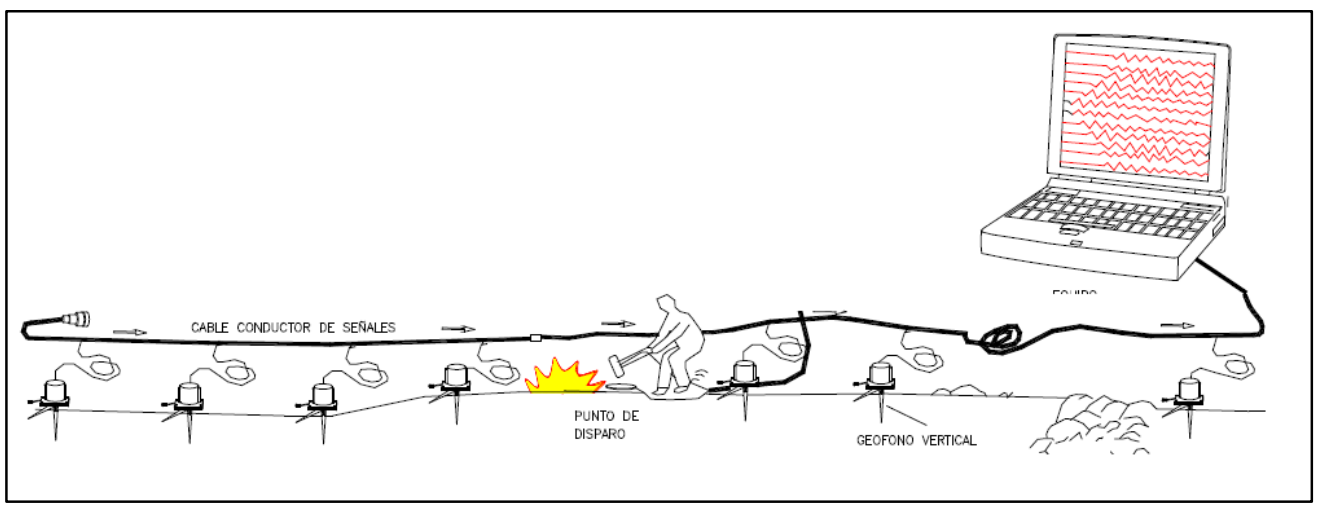

Gráfico $\mathrm{N}^{\circ}$ 02: Diagrama del ensayo de refracción sísmica 
Los datos consisten en tiempos de viajes y distancias, siendo el tiempo de viaje el intervalo entre el tiempo cero y el instante en que el detector empieza a responder a la perturbación. Esta información tiempo-distancia (Dromocrónica) es procesada para obtener una interpretación en la forma de velocidades de propagación de ondas y la estructura de los estratos del subsuelo, según se observa en la Gráfico № 03.

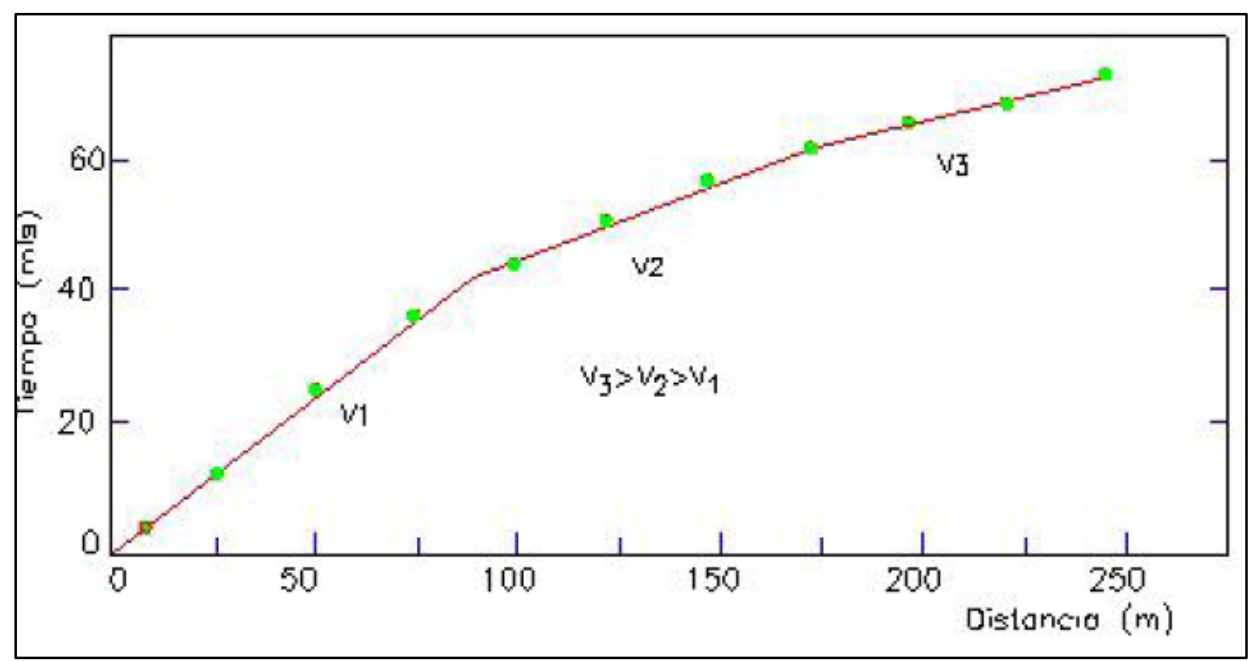

Gráfico $N^{\circ} 03:$ Dromocrónica del ensayo de refracción sísmica

Los datos de tiempo y distancia obtenidos para diferentes ubicaciones del punto de aplicación de la energía (shot), permite determinar las velocidades de propagación de ondas $\mathrm{P}$ a través de los diferentes estratos de suelos y rocas cuya estructura, geometría y continuidad son investigadas.

\subsection{Equipo y Software}

Para realizar las líneas de refracción sísmica se contó con un equipo de prospección geofísica SMARTSEIS ST, desarrollado por la empresa GEOMETRICS, el cual tiene las siguientes características:

- 24 canales de entrada, cada uno tiene un convertidor A/D individual con resolución de 24 bit y alta velocidad de muestreo.

- 24 sensores o geófonos de $14 \mathrm{~Hz}$ de frecuencia, los cuales permiten registrar las vibraciones ambientales del terreno producidas por fuentes naturales o artificiales y el arribo de las ondas $\mathrm{P}$ generadas por las fuentes de energía.

- Computadora portátil integrada al sistema de adquisición.

- Un cable de conectores de geófonos de $120 \mathrm{~m}$.

- Una comba de $20 \mathrm{lb}$ con los platos para el shot

- Radios de comunicación y accesorios varios.

Los registros de las ondas sísmicas obtenidas en cada una de las líneas de exploración 
pueden ser procesados en el campo en forma preliminar y en forma definitiva en el gabinete, utilizando para ello programas de cómputo que permiten obtener las velocidades de propagación de las ondas $\mathrm{P}$, así como el perfil sísmico unidimensional del terreno.

El procesamiento de las líneas sísmicas de refracción se realizó con ayuda del Software PICKWIN y PLOTREFA 2D V2.0 con lo cual se obtienen los perfiles sísmicos, velocidades y espesores de los horizontes elásticos existentes.

\subsection{Trabajos de Campo}

Los trabajos de campo en el área de estudio consistió en realizar líneas de refracción sísmica, éstos fueron dispuestos alredor del Parque Arqueológico de Saqsaywamán para estos métodos, se adecuó a la disponibilidad del espacio con la finalidad de detectar la profundidad de los estratos que conforman el terreno y la posible ubicación de las cimentaciones de las murallas existentes.

Para la ejecución de cada ensayo primero se define el eje de la línea sísmica, luego se procede a instalar los geófonos y los cables de conexión al equipo de adquisición de datos. El espaciamiento entre geófonos es definido en función de la profundidad de exploración requerida y del área libre disponible en la zona de trabajo.

La investigación geofísica consistió en la exploración del terreno ejecutándose 34 líneas de Refracción Sísmica, con una longitud total de 1007 metros con separación entre geófonos de $0.46 \mathrm{~m}$ a $2.50 \mathrm{~m}$, definiéndose la potencia de los estratos que conforman el terreno sobre el que se encuentra el Parque Arqueológico de Saqsaywamán. La fuente de energía utilizada para generar las ondas sísmicas consistió en una comba de $20 \mathrm{lb}$. El uso de esta fuente de energía permitió obtener registros de ondas con la adecuada nitidez para las longitudes de líneas ejecutadas. Asimismo se han realizado 147 Lineas de Georadar (GPR) con una longitud total de 2350 metros

En los anexos se presenta la Figura Nro. 01 donde se muestra la ubicación en planta de los sondajes realizados.

En el Cuadro $\mathrm{N}^{\circ} 01$ se presenta el resumen de las líneas de refracción sísmica, las longitudes de tendido y la separación entre geófonos dispuestos en campo. 
Cuadro $N^{\circ} 01:$ Resumen de las líneas de refracción sísmica

\begin{tabular}{|c|c|c|c|}
\hline $\begin{array}{c}\text { Línea Sísmica } \\
\text { Ls-i }\end{array}$ & $\begin{array}{l}\text { Tipo de } \\
\text { Onda }\end{array}$ & $\begin{array}{l}\text { Longitud Tendido } \\
\text { Sísmico } \\
(\mathrm{m})\end{array}$ & $\begin{array}{c}\text { Separación entre } \\
\text { Geófonos } \\
(\mathrm{m})\end{array}$ \\
\hline Ls-01 & $P$ & 36 & 1.50 \\
\hline Ls-02 & $P$ & 36 & 1.50 \\
\hline LS-03 & $P$ & 36 & 1.50 \\
\hline LS-04 & $P$ & 30.5 & 1.27 \\
\hline LS-05 & $P$ & 35.4 & 1.48 \\
\hline LS-06 & $\mathrm{P}$ & 30.5 & 1.27 \\
\hline LS-07 & $P$ & 48 & 2.00 \\
\hline LS-08 & $P$ & 48 & 2.00 \\
\hline LS-09 & $P$ & 60 & 2.50 \\
\hline LS-10 & $P$ & 11 & 0.46 \\
\hline LS-11 & $P$ & 48 & 2.00 \\
\hline LS-13 & $P$ & 48 & 2.00 \\
\hline LS-14 & $P$ & 48 & 2.00 \\
\hline LS-15 & $P$ & 30 & 1.25 \\
\hline LS-16 & $P$ & 33.6 & 1.40 \\
\hline LS-17 & $P$ & 36 & 1.50 \\
\hline LS-18 & $P$ & 36 & 1.50 \\
\hline LS-19 & $P$ & 36 & 1.50 \\
\hline LS-20 & $P$ & 36 & 1.50 \\
\hline LS-21 & $P$ & 36 & 1.50 \\
\hline LS-22 & $P$ & 36 & 1.50 \\
\hline LS-23 & $P$ & 36 & 1.50 \\
\hline LS-24 & $P$ & 36 & 1.50 \\
\hline LS-25 & $P$ & 11 & 0.46 \\
\hline
\end{tabular}




\begin{tabular}{|c|c|c|c|}
\hline LS-26 & P & 12 & 0.50 \\
\hline LS-27 & $P$ & 12 & 0.50 \\
\hline LS-28 & $\mathrm{P}$ & 12 & 0.50 \\
\hline LS-29 & $\mathrm{P}$ & 12 & 0.50 \\
\hline LS-30 & $\mathrm{P}$ & 12 & 0.50 \\
\hline LS-31 & $\mathrm{P}$ & 14.4 & 0.60 \\
\hline LS-32 & $\mathrm{P}$ & 14.4 & 0.60 \\
\hline LS-33 & $\mathrm{P}$ & 16.8 & 0.70 \\
\hline LS-34 & $\mathrm{P}$ & 24 & 1.00 \\
\hline
\end{tabular}

\subsection{Resultados de los Ensayos Geofísicos}

A continuación se presenta los resultados de las líneas representativas identificadas con anomalías, en posibles ejes de muros incas, de acuerdo a sus velocidades de ondas $\mathrm{P}$ y la intensidad de reflexión de las ondas electromagnéticas. En el Cuadro $\mathrm{N}^{\circ} 02$ se muestra los resultados del ensayo de refracción sísmica correspondiente a la zona de estudio. En el anexo 02 se muestra una comparación grafica de los resultados entre las líneas de refracción sísmica y las líneas de georadar.

\section{Cuadro N02: Resultado de las Líneas Geofísicas}

\begin{tabular}{|c|c|c|c|c|}
\hline LINEA & $\mathbf{V p}(\mathbf{m} / \mathbf{s})$ & $\begin{array}{c}\text { Distancia desde el } \\
\text { punto de inicio del } \\
\text { ensayo }(\mathbf{m})\end{array}$ & Descripción & LINEA - GPR \\
\hline LS-01 & - & - & - & L-109-L1/ L-109-L2 \\
\hline LS-02 & - & - & - & L-109-L3/ L-109-L4 \\
\hline LS-03 & $500-600$ & $23.0 m$ & Probable ubicación del eje de muro inca & L-137-L1 \\
\hline LS-04 & - & $30.0 m$ & - & $\begin{array}{c}\text { L- 122-DE L1 HASTA } \\
\text { L21/ / L-124-L4-L5 }\end{array}$ \\
\hline LS-05 & $500-600$ & $29.0 m$ & Probable ubicación del eje de muro inca & $\begin{array}{c}\text { L- 122-DE L1 HASTA } \\
\text { L21 / L-124-L1-L2-L3 }\end{array}$ \\
\hline LS-06 & $500-600$ & $12.0 m$ & Probable ubicación del eje de muro inca & $\begin{array}{c}\text { L-137-L1/L-137-L2/ } \\
\text { L137-L4 }\end{array}$ \\
\hline LS-07 & $500-600$ & $31.0 m$ & Probable ubicación del eje de muro inca & L-139-L1/ L-137-L3 \\
\hline LS-08 & - & - & & - \\
\hline LS-09 & $500-600$ & $54.0 m$ & Probable ubicación del eje de muro inca & L-146-L3/ L-146-L2 \\
\hline LS-10 & $500-600$ & $5.0 m$ & Probable ubicación del eje de muro inca & $\begin{array}{c}\text { L- 122-DE L1 HASTA } \\
\text { L21 }\end{array}$ \\
\hline LS-11 & $500-600$ & $29.0 m$ & Probable ubicación del eje de muro inca & L-148-L1/ L-147-L1 \\
\hline
\end{tabular}




\begin{tabular}{|c|c|c|c|c|}
\hline LS-12 & - & - & - & - \\
\hline LS-13 & $\begin{array}{c}450-700 / \\
700-900 \\
\end{array}$ & $22.0 \mathrm{~m} / 38.0 \mathrm{~m}$ & Probable ubicación del eje de muro inca & L-161-L2 \\
\hline LS-14 & $\begin{array}{c}450-700 / \\
700-900\end{array}$ & $8.0 \mathrm{~m} / 23.0 \mathrm{~m} / 40.0 \mathrm{~m}$ & Probable ubicación del eje de muro inca & L-161-L1 \\
\hline LS-15 & - & - & - & L-149 \\
\hline LS-16 & - & - & - & $\begin{array}{c}\text { L-154-L1 / L-154-L2/ } \\
\text { L-154-L3 }\end{array}$ \\
\hline LS-17 & $500-650$ & $13.0 \mathrm{~m}$ & Probable ubicación del eje de muro inca & L-160-L1 \\
\hline LS-18 & $500-700$ & $19.5 \mathrm{~m} / 30 \mathrm{~m}$ & Probable ubicación del eje de muro inca & L-158-L3 \\
\hline LS-19 & $450-550$ & $1.0 \mathrm{~m} / 14.0 \mathrm{~m} / 28.0 \mathrm{~m}$ & Probable ubicación del eje de muro inca & L-159-L1 \\
\hline LS-20 & $500-600$ & $11.0 \mathrm{~m} / 26.0 \mathrm{~m}$ & Probable ubicación del eje de muro inca & L-159-L2 \\
\hline LS-21 & $500-600$ & $15.0 \mathrm{~m} / 25.0 \mathrm{~m}$ & Probable ubicación del eje de muro inca & L-158-L2/L-160-L2 \\
\hline LS-22 & 450 & $1.0 \mathrm{~m}$ & Probable ubicación del eje de muro inca & L-159-L3 \\
\hline LS-23 & 450 & $6.0 \mathrm{~m} / 28.0 \mathrm{~m}$ & Probable ubicación del eje de muro inca & L-158-L1 \\
\hline LS-24 & - & - & - & L-124-L6 \\
\hline LS-25 & $700-1200$ & $4.5 \mathrm{~m}$ & Probable ubicación del eje de muro inca & L-164-L2 \\
\hline LS-26 & $700-1200$ & $6.0 \mathrm{~m}$ & Probable ubicación del eje de muro inca & L-164-L1 \\
\hline LS-27 & $500-700$ & $5.6 \mathrm{~m} / 9.5 \mathrm{~m}$ & Probable ubicación del eje de muro inca & L-163-L2/ L-162-L1 \\
\hline LS-28 & 500 & $5.0 \mathrm{~m}$ & Probable ubicación del eje de muro inca & L-163-L1/ L-162-L2 \\
\hline LS-29 & $500-700$ & $4.0 \mathrm{~m}$ & Probable ubicación del eje de muro inca & L-165-L1 \\
\hline LS-30 & $500-600$ & $5.0 \mathrm{~m} / 8.0 \mathrm{~m}$ & Probable ubicación del eje de muro inca & L-165-L2 \\
\hline LS-31 & 700 & $5.0 \mathrm{~m}$ & Probable ubicación del eje de muro inca & L-165-L3 \\
\hline LS-32 & $700-900$ & $4.5 \mathrm{~m}$ & Probable ubicación del eje de muro inca & L-165-L4 \\
\hline LS-33 & $700-900$ & $3.5 \mathrm{~m}$ & Probable ubicación del eje de muro inca & L-166-L1 \\
\hline LS-34 & $700-900$ & $4.0 \mathrm{~m} / 15.0 \mathrm{~m}$ & Probable ubicación del eje de muro inca & L-166-L2 \\
\hline
\end{tabular}

De los resultados obtenidos se aprecia que las condiciones estratigráficas de los suelos del Parque Arqueologico de Saqsayhuamán presentan velocidades de ondas Vp que varían de $300 \mathrm{~m} / \mathrm{s}-2300 \mathrm{~m} / \mathrm{s}$.

\section{CONCLUSIONES}

Los resultados de los ensayos geofísicos nos proporcionaron evidencias de presencia de muros incas y terrazas que se encuentran actualmente cubiertas y cuya ubicación es fundamental para mejorar el sistema de drenaje existente y disminuir los esfuerzos que han venido ocasionando el colapso de los muros en la tercera terraza. 
Se ha determinado velocidades de ondas $V p$ en el Parque Arqueologico de Saqsayhuamán obteniendo velocidades de ondas Vp que varían de $300 \mathrm{~m} / \mathrm{s}-2300$ $\mathrm{m} / \mathrm{s}$.

\section{B. SUPPLEMENTARY SUBSURFACE DATA DOCUMENTATION}

1. Table B1: GPR Run Attributes

\begin{tabular}{|r|r|r|r|r|r|l|}
\hline OBJECTID & $\begin{array}{c}\text { Z_Min } \\
\text { [meters] }\end{array}$ & $\begin{array}{c}\text { Z_Max } \\
\text { [meters] }\end{array}$ & $\begin{array}{c}\text { Length3D } \\
\text { [meters] }\end{array}$ & $\begin{array}{c}\text { Avg_Slope } \\
\text { [\%] }\end{array}$ & $\begin{array}{c}\text { Shape_Length } \\
\text { [meters] }\end{array}$ & Name_Description \\
\hline 1 & 3609.96 & 3610.77 & 11.79 & 6.90 & 11.76 & EastWoods 11 \\
\hline 2 & 3608.52 & 3609.15 & 22.29 & 2.83 & 22.28 & EastWoods 9 \\
\hline 3 & 3609.35 & 3609.96 & 7.81 & 7.77 & 7.79 & EastWoods 7 \\
\hline 4 & 3609.14 & 3609.40 & 7.29 & 3.59 & 7.28 & EastWoods 6 \\
\hline 5 & 3614.27 & 3614.60 & 5.74 & 5.67 & 5.74 & EastWoods 5 \\
\hline 6 & 3614.26 & 3614.65 & 11.83 & 3.31 & 11.83 & EastWoods 4 \\
\hline 7 & 3612.87 & 3613.43 & 24.20 & 2.29 & 24.20 & EastWoods 3 \\
\hline 8 & 3607.85 & 3608.55 & 23.47 & 3.03 & 23.46 & EastWoods 2 \\
\hline 9 & 3607.48 & 3608.25 & 21.67 & 3.58 & 21.66 & EastWoods 1 \\
\hline 10 & 3610.15 & 3613.40 & 59.02 & 5.52 & 58.93 & EastHill 14 \\
\hline 11 & 3608.96 & 3611.38 & 42.78 & 5.68 & 42.71 & EastHill 13 \\
\hline 12 & 3608.39 & 3610.15 & 39.41 & 4.48 & 39.37 & EastHill 12 \\
\hline 13 & 3606.76 & 3610.60 & 53.06 & 7.25 & 52.92 & EastHill 11 \\
\hline 14 & 3616.45 & 3619.70 & 24.83 & 13.20 & 24.62 & EastHill 9 \\
\hline 15 & 3615.19 & 3621.18 & 34.05 & 17.85 & 33.52 & EastHill 8 \\
\hline 16 & 3614.90 & 3615.38 & 36.34 & 1.31 & 36.34 & EastHill 6 \\
\hline 17 & 3613.54 & 3613.72 & 11.75 & 1.48 & 11.75 & EastHill 5 \\
\hline 18 & 3612.05 & 3615.50 & 33.22 & 10.44 & 33.04 & EastHill 4 \\
\hline 19 & 3613.30 & 3617.80 & 32.86 & 13.82 & 32.55 & EastHill 3 \\
\hline 20 & 3610.30 & 3612.24 & 31.90 & 6.09 & 31.84 & EastHill 1 \\
\hline 21 & 3608.01 & 3616.93 & 31.94 & 29.07 & 30.67 & EastHill 15 \\
\hline 22 & 3608.91 & 3609.48 & 8.33 & 6.84 & 8.33 & EastWoods 10 \\
\hline & & & & & & \\
\hline
\end{tabular}


2. Figure B1: GPR Runs

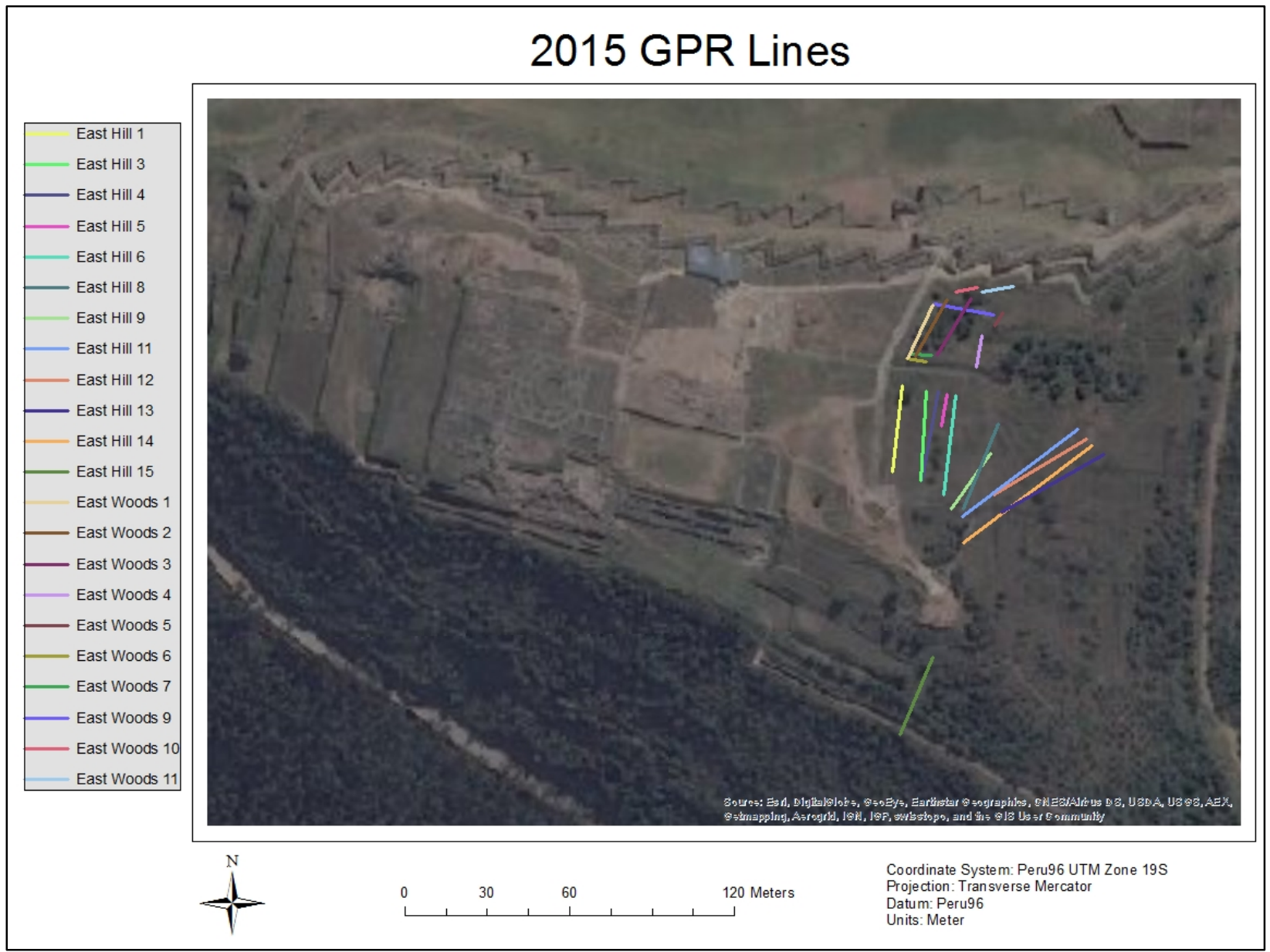


3. Table B2: Seismic Refraction Run Attributes

\begin{tabular}{|r|r|r|r|r|r|l|}
\hline OBJECTID & $\begin{array}{c}\text { Z_Min } \\
\text { [meters] }\end{array}$ & $\begin{array}{c}\text { Z_Max } \\
\text { [meters] }\end{array}$ & $\begin{array}{c}\text { Length3D } \\
\text { [meters] }\end{array}$ & $\begin{array}{c}\text { Avg_Slope } \\
\text { [\%] }\end{array}$ & $\begin{array}{c}\text { Shape_Length } \\
\text { [meters] }\end{array}$ & Name_Description \\
\hline 1 & 3611.10 & 3615.29 & 39.09 & 10.78 & 38.87 & Seismic 13 \\
\hline 2 & 3617.52 & 3617.95 & 53.48 & 0.80 & 53.48 & Seismic 14 \\
\hline 3 & 3613.07 & 3613.63 & 32.44 & 1.74 & 32.44 & Seismic 16 \\
\hline 4 & 3611.75 & 3612.18 & 38.17 & 1.11 & 38.17 & Seismic 17 \\
\hline 5 & 3608.10 & 3609.98 & 32.69 & 5.74 & 32.64 & Seismic 18 \\
\hline 6 & 3610.87 & 3611.16 & 35.16 & 0.83 & 35.16 & Seismic 19 \\
\hline 7 & 3607.48 & 3608.60 & 35.25 & 3.19 & 35.23 & Seismic 20 \\
\hline 8 & 3610.55 & 3611.63 & 16.68 & 6.46 & 16.65 & Seismic 21 \\
\hline 9 & 3600.90 & 3603.93 & 34.13 & 8.91 & 33.99 & Seismic 22 \\
\hline 10 & 3610.64 & 3612.65 & 34.47 & 5.84 & 8.16 & Seismic 25 \\
\hline 11 & 3601.51 & 3603.67 & 8.45 & 26.52 & 5.63 & Seismic 26 \\
\hline 12 & 3583.12 & 3593.93 & 12.19 & 192.19 & 6.22 & Seismic 27.1 \\
\hline 13 & 3615.41 & 3616.37 & 6.29 & 15.35 & 2.33 & Seismic 27.2 \\
\hline 14 & 3616.20 & 3617.85 & 2.85 & 70.83 & 3.76 & Seismic 28.1 \\
\hline 15 & 3616.04 & 3616.50 & 3.79 & 12.23 & 3.20 & Seismic 28.2 \\
\hline 16 & 3614.56 & 3614.85 & 3.21 & 8.91 & 10.33 & Seismic 29 \\
\hline 17 & 3611.29 & 3611.79 & 10.34 & 4.86 & 11.16 & Seismic 30 \\
\hline 18 & 3611.72 & 3612.24 & 11.17 & 4.64 & 9.95 & Seismic 31 \\
\hline 19 & 3610.37 & 3611.35 & 10.00 & 9.83 & 10.66 & Seismic 32 \\
\hline 20 & 3612.85 & 3614.09 & 10.73 & 11.57 & 11.01 & Seismic 33 \\
\hline 21 & 3616.96 & 3617.20 & 11.01 & 2.18 & 19.99 & Seismic 34 \\
\hline 22 & 3610.47 & 3612.64 & 20.10 & 10.87 & & \\
\hline & & & & & & \\
\hline
\end{tabular}


4. Figure B2: Seismic Runs

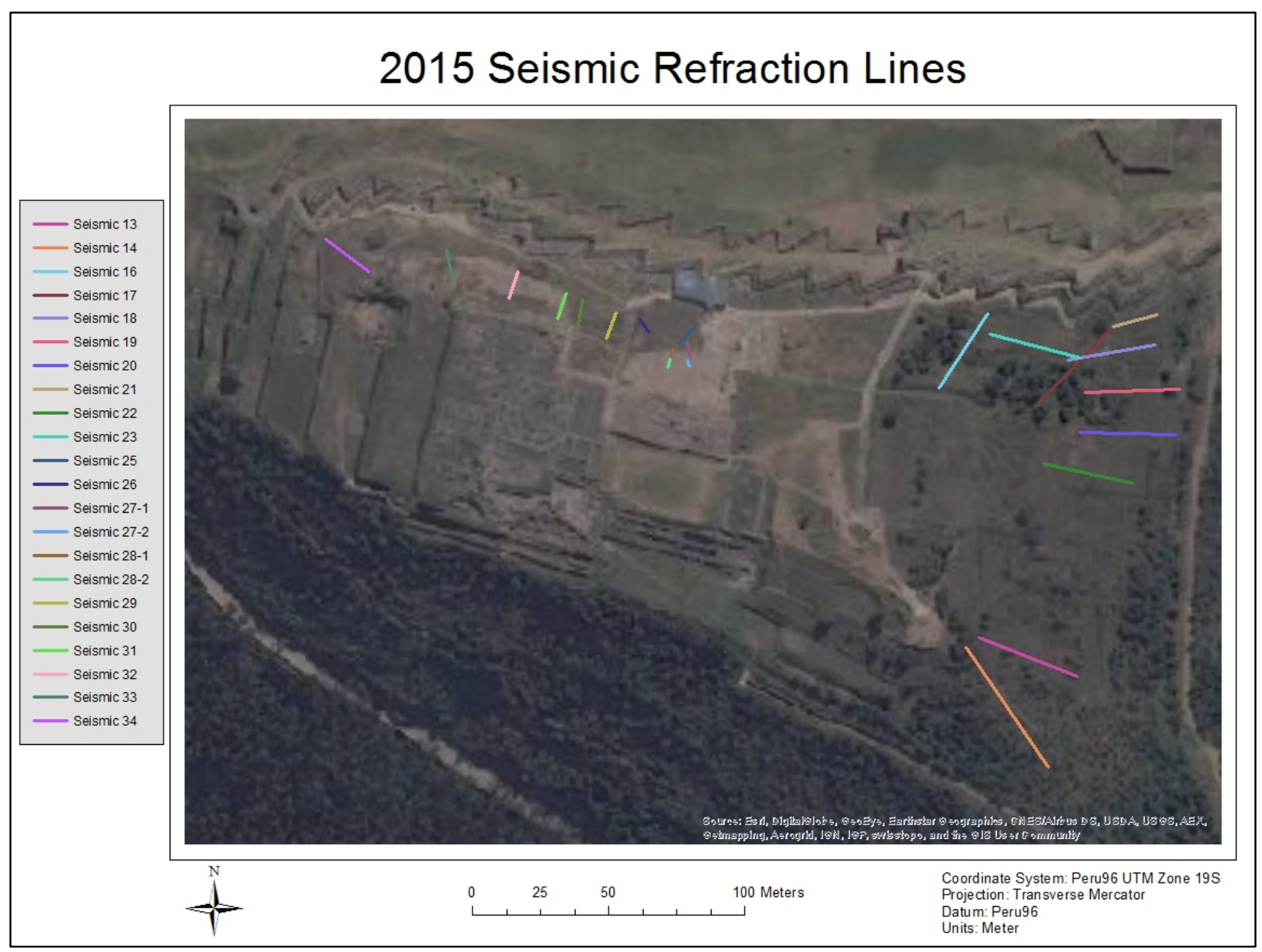

